\title{
Redox Signaling from and to Peroxisomes: Progress, Challenges and Prospects
}

Marc Fransen and Celien Lismont

Laboratory of Lipid Biochemistry and Protein Interactions, Department of Cellular and Molecular Medicine, KU Leuven - University of Leuven, B-3000 Leuven, Belgium.

Correspondence: Prof. Dr. Marc Fransen, Laboratory of Lipid Biochemistry and Protein Interactions, Department of Cellular and Molecular Medicine, KU Leuven - University of Leuven, B-3000 Leuven, Belgium (phone: +32 16 330114; fax: +32 16330642 ; e-mail address: marc.fransen@kuleuven.be)

Running head: Peroxisomes and Cellular Redox Control

Word count: 7921 (excluding references and figure legends)

Reference numbers: 187

Greyscale illustrations: 0

\section{Color illustrations: 6}

Keywords: Peroxisomes, hydrogen peroxide, catalase, redox balance, organelle dysfunction, disease 


\section{ABSTRACT}

Significance: Peroxisomes are organelles that are best known for their role in cellular lipid and hydrogen peroxide $\left(\mathrm{H}_{2} \mathrm{O}_{2}\right)$ metabolism. Emerging evidence suggests that these organelles serve as guardians and modulators of cellular redox balance, and that alterations in their redox metabolism may contribute to aging and the development of chronic diseases such as neurodegeneration, diabetes, and cancer. Recent Advances: $\mathrm{H}_{2} \mathrm{O}_{2}$ is an important signaling messenger that controls many cellular processes by modulating protein activity through cysteine oxidation. Somewhat surprisingly, the potential involvement of peroxisomes in $\mathrm{H}_{2} \mathrm{O}_{2}$ mediated signaling processes has been overlooked for a long time. However, recent advances in the development of live-cell approaches to monitor and modulate spatiotemporal fluxes in redox species at the subcellular level have opened up new avenues for research in redox biology and boosted interest in the concept of peroxisomes as redox signaling platforms. Critical Issues: This review first introduces the reader to what is known about the role of peroxisomes in cellular $\mathrm{H}_{2} \mathrm{O}_{2}$ production and clearance, with a focus on mammalian cells. Next, it briefly describes the benefits and drawbacks of current strategies employed to investigate the complex interplay between peroxisome metabolism and cellular redox state. Furthermore, it integrates and critically evaluates literature dealing with the interrelationship between peroxisomal redox metabolism, cell signaling, and human disease. Future Directions: As the precise molecular mechanisms underlying many of these associations are still poorly understood, a key focus for future research should be the identification of primary targets for peroxisome-derived $\mathrm{H}_{2} \mathrm{O}_{2}$. 


\section{INTRODUCTION}

Cell functioning is crucially dependent on the proper synchronization of specific biochemical reactions in a spatiotemporally-controlled manner (153). As many of these reactions require the transfer of electrons from one atom or molecule to another, reductionoxidation (redox) processes and associated signaling are essential to sustain life. The redox state within a cell is reflected by the degree of oxidation (or reduction) of various redox-active molecules (e.g., protein cysteine thiols, glutathione, pyridine nucleotides, coenzyme A, etc.) and can differ in distinct compartments and over time $(100,144)$. Changes in local or systemic pro-oxidant and/or antioxidant activity can be expected to cause redox stress, a condition that can trigger diverse cellular responses ranging from subtle modulations of cell signaling to severe oxidative damage (130). Whether oxidants serve as signaling molecules for normal cellular function or cause damage to a variety of biomolecules depends on multiple factors, including their type, concentration, location, and kinetics of production and elimination (11). Major sites of cellular oxidant production include the mitochondrial respiratory chain (5), endoplasmic reticulum oxidoreductase 1 (187), the peroxisomal flavin-containing oxidases (54), and the NADPH oxidases (117) and nitric oxide synthases (60) that are located in distinct subcellular locations. To control the harmful effects of reactive oxygen and nitrogen species (ROS and RNS, respectively), cells possess both enzymatic (e.g., superoxide dismutases, catalase, glutaredoxins, thioredoxins, and peroxiredoxins) and non-enzymatic (e.g., reduced gluthathione (GSH), ascorbic acid, $\alpha$-tocopherol, and lipoic acid) antioxidant defense systems $(67,108,131)$. Currently, it is widely accepted that cells can sense changes in redox balance through selective oxidation or reduction of protein cysteines by ROS, and especially $\mathrm{H}_{2} \mathrm{O}_{2}$ (Fig. 1). Importantly, as (i) redox-related posttranslational modifications often serve as "on" or "off" switches that regulate protein activity, localization, and/or their ability to interact with other biomolecules $(1,132)$, and (ii) a wide spectrum of functionally unrelated proteins contains such 
redox-sensitive cysteines (129), these residues can be considered as molecular switches that regulate diverse cellular processes in response to oxidative stress (Fig. 1). As such, it is not surprising that perturbations in cellular $\mathrm{H}_{2} \mathrm{O}_{2}$ metabolism can elicit physiological adaptive responses (e.g., an enhanced antioxidant defense) and impact on various disease conditions (Fig. 2) $(10,95,156,163)$.

In the following sections, we first provide a brief overview of the key features of peroxisomal redox metabolism, with a focus on $\mathrm{H}_{2} \mathrm{O}_{2}$. Next, we outline the various strategies that are currently employed to study the role of peroxisomes in cellular redox homeostasis and signaling, including their benefits and drawbacks. Furthermore, we critically review and discuss emerging evidence that alterations in peroxisomal redox metabolism can influence cell fate decisions and disease pathogenesis. Finally, we outline several key research questions that, if addressed, would move the field forward.

\section{PEROXISOME FUNCTION AND REDOX STATE}

\section{Peroxisomes and their role in cell metabolism}

Peroxisomes are ubiquitous cell organelles that are traditionally recognized for their role in cellular lipid metabolism (e.g., $\alpha$ - and $\beta$-oxidation of fatty acids; the biosynthesis of ether-phospholipids and bile acids; and the $\beta$-oxidation-mediated shortening of tetracosahexaenoic acid to docosahexaenoic acid through a process called "retroconversion") (164, 175). Other important metabolic functions of peroxisomes include glyoxylate detoxification, amino acid catabolism, and polyamine oxidation (172). A substantial subset of the enzymes involved in these pathways are flavin-containing oxidoreductases, which produce $\mathrm{H}_{2} \mathrm{O}_{2}$ as part of their normal catalytic activity (6). Peroxisomes also contain two potential enzymatic sources of superoxide $\left(\mathrm{O}_{2}{ }^{\bullet-}\right)$ and nitric oxide $\left({ }^{\bullet} \mathrm{NO}\right)$, namely xanthine oxidase and the inducible form of nitric oxide synthase (NOS2) (54). To prevent ROS/RNS damage, the 
organelles are equipped with multiple enzymatic (e.g., catalase (CAT) and peroxiredoxin-5 (PRDX5)) and non-enzymatic (e.g., ascorbic acid and glutathione) antioxidant defense systems (54). Perturbations in any of these metabolic processes can directly or indirectly be linked to a growing number of diseases, ranging from rare genetic disorders such as Zellweger syndrome to more common age-related disorders $(55,41,175)$.

\section{Peroxisomes as a source and sink for $\mathrm{H}_{2} \mathrm{O}_{2}$}

As can be inferred from their name, peroxisomes harbor enzymes involved in the production and degradation of $\mathrm{H}_{2} \mathrm{O}_{2}$ (Fig. 3) (40). In mammals, the main substrates oxidized by peroxisomal $\mathrm{H}_{2} \mathrm{O}_{2}$-producing oxidases include fatty acyl-CoAs, D-amino acids, L- $\alpha$ hydroxy acids, polyamines, and L-pipecolic acid (6). The resulting $\mathrm{H}_{2} \mathrm{O}_{2}$ can be enzymatically scavenged by CAT, PRDX5, or glutathione peroxidase (GPX) (6). CAT is a predominantly peroxisomal heme-containing enzyme that can degrade $\mathrm{H}_{2} \mathrm{O}_{2}$ in a catalatic $\left(2 \mathrm{H}_{2} \mathrm{O}_{2} \rightarrow 2 \mathrm{H}_{2} \mathrm{O}\right.$ $\left.+\mathrm{O}_{2}\right)$ or peroxidatic $\left(\mathrm{H}_{2} \mathrm{O}_{2}+\mathrm{AH}_{2} \rightarrow \mathrm{A}+2 \mathrm{H}_{2} \mathrm{O} ; \mathrm{AH}_{2}\right.$ and $\mathrm{A}$ represent, respectively, the reduced and oxidized forms of a suitable electron donor) manner (84). The catalatic reaction is one of the fastest enzymatic reactions known and proportional to the concentration of $\mathrm{H}_{2} \mathrm{O}_{2}$. At low concentrations of $\mathrm{H}_{2} \mathrm{O}_{2}$ and in the presence of a suitable hydrogen donor, the peroxidatic reaction dominates over the catalatic reaction (84). PRDX5 is a cysteine-based peroxidase that is located in distinct subcellular compartments, including peroxisomes, and uses thioredoxins to reduce alkyl hydroperoxides, peroxynitrite, and - albeit to a lesser extent - also $\mathrm{H}_{2} \mathrm{O}_{2}(87)$. Given that currently no thioredoxin has been identified in mammalian peroxisomes, it remains unclear how oxidized PRDX5 is reduced back to its active thiol form within this compartment. Already more than a decade ago, it has been demonstrated that rat liver peroxisomes also contain GPX activity, a family of antioxidant enzymes that typically use reduced glutathione (GSH) as co-substrate (158). However, the molecular identity of this protein remains to be 
determined. In addition, it is unclear how GSH and/or oxidized glutathione (GSSG) are transported across the peroxisomal membrane and whether or not mammalian peroxisomes contain a functional glutathione redox system (54).

An important but still unresolved question in the field is whether peroxisomes act as net sources or sinks for $\mathrm{H}_{2} \mathrm{O}_{2}$. However, given that (i) local concentrations of $\mathrm{H}_{2} \mathrm{O}_{2}$ are directly determined by their relative rates of synthesis, diffusion, and clearance (7), and (ii) peroxisomes are metabolically plastic organelles that modulate their size, shape, number, and protein content in response to changing developmental and environmental needs (53), it can be expected that - depending on the species, tissue, cell type, and physiological condition - these organelles may act either as a source or sink for $\mathrm{H}_{2} \mathrm{O}_{2}$. Of course, a conditio sine qua non is that this molecule can move bidirectionally across the peroxisomal membrane. That this indeed happens is supported by multiple lines of evidence. For example, already more than 40 years ago, in vitro studies clearly demonstrated that $20-60 \%$ of all $\mathrm{H}_{2} \mathrm{O}_{2}$ that is generated inside purified rat liver peroxisomes upon supplementation of uric acid can readily diffuse into the surrounding medium, despite the organelle's high CAT content (22). In addition, in cellulo studies have extended these in vitro data by showing that peroxisome-derived $\mathrm{H}_{2} \mathrm{O}_{2}$ can increase nuclear NF-kB DNA-binding activity in a dose-dependent manner in SV40 large Tantigen-transformed African green monkey kidney (COS-1) cells (97). Furthermore, mouse tissular studies have shown that slices of liver, lung, and lenses from CAT-deficient mice exhibit a retarded rate in consuming extracellular $\mathrm{H}_{2} \mathrm{O}_{2}$ compared to those of wild-type mice, indicating that the oxidant can actually also diffuse from the cytoplasm into the peroxisome lumen (73). Unfortunately, the identity of the protein(s) that facilitate(s) $\mathrm{H}_{2} \mathrm{O}_{2}$ diffusion across the peroxisomal membrane remains to be established. A potential candidate may be the peroxisomal membrane protein PXMP2, a non-selective pore-forming protein with an upper molecular size limit of 300-600 Da (140). 


\section{Peroxisomes and cellular redox state}

To carry out their functions, peroxisomes physically and functionally interact with other cell organelles (155), and disturbances in peroxisome function have been demonstrated to affect the redox state of multiple subcellular compartments. For example, defects in peroxisome biogenesis shift the cytosolic redox equilibrium to a more reduced state in Chinese hamster ovary $(\mathrm{CHO})$ cells $(180)$ and promote oxidative stress in mitochondria $(15,134)$ and the ER (90) of mouse liver hepatocytes. In addition, CAT inhibition has been shown to increase global protein disulfide levels in (human) Chang liver cells by $20 \%$ (179) and to rapidly enhance mitochondrial ROS levels in mouse and human fibroblasts $(75,171)$. Furthermore, also lack of $\mathrm{ABCD} 1$, a peroxisomal transporter of $\beta$-oxidation substrates and the causative protein for X-linked adrenoleukodystrophy (X-ALD) (17), is known to increase mitochondrial oxidative stress in the spinal cord from $A b c d^{-/}$mice and human X-ALD fibroblasts $(51,105)$. Interestingly, the decrease in cytosolic redox state observed in peroxisome biogenesis-deficient CHO cell mutants appears to be caused by degradation of mislocalized acyl-CoA oxidase 1 (ACOX1), a major peroxisomal $\mathrm{H}_{2} \mathrm{O}_{2}$-generating enzyme, rather than mislocalization of peroxisomal CAT (180). Also, given that acute elimination of peroxisomes in livers of adult mice yielded similar mitochondrial defects (e.g., ultrastructural abnormalities, increased oxidative stress, reduced mitochondrial DNA abundance) as those observed in livers of adult mice in which peroxisome function was chronically deleted from hepatocytes since birth, it is unlikely that the observed phenotype reflects a long-term adaptation to peroxisome deficiency (134).

Mounting evidence suggests that changes in the intracellular redox state also influence peroxisome number and activity. For example, it has been reported that chronic exposure of cells to oxidative stress (e.g., during cellular aging $(75,94)$, in diseased cells $(178)$, or upon long term CAT inhibition $(89,171))$ may elevate peroxisome number, although not with a 
corresponding increase in peroxisomal enzyme activities (171). Other studies have shown that acute exposure of various human and rat cell lines to external or internal ROS attacks promotes peroxisome degradation $(76,186)$. To better understand the potential mechanisms underlying these apparently conflicting observations, it is essential to highlight that PEX5, the cycling import receptor for peroxisomal matrix proteins containing a C-terminal peroxisomal targeting signal (PTS1), can undergo thiol-sensitive (on Cys11 in human PEX5) and thiol-resistant (on Lys209 and Lys527 in human PEX5) ubiquitin modifications (32, 125, 186). Cys-linked PEX5 monoubiquitination (Ubcys-PEX5) is a redox-sensitive process that serves to extract the receptor out of the peroxisomal membrane for another round of import $(8,52)$. Oxidative stress conditions slowing down this process reduce the import efficiency of PTS1 proteins, particularly those containing a weak targeting signal (e.g., CAT) (8). In addition, accumulation of Ubcys-PEX5 at the membrane can trigger peroxisome degradation, at least under certain conditions (121). In light of these observations, it is not surprising that chronic increases in redox state result in the accumulation of (non-ubiquitinated) PEX5 at the peroxisomal membrane, a partial mislocalization of CAT to the cytosol, and an increase in peroxisome number $(8,94,159,171)$. Finally, a study aimed at identifying the molecular mechanisms underlying peroxisome degradation in response to acute oxidative stress has demonstrated that this process is mediated through (i) activation of the peroxisomal pool of the serine/threonine kinase ATM, (ii) phosphorylation of PEX5 at Ser141, which promotes PEX5 monoubiquitylation at Lys209, and (iii) recognition of UbLys209-PEX5 by the autophagy receptor protein SQSTM1 (186). In summary, these findings clearly demonstrate that peroxisomes have the capacity to actively sense and respond to changes in their redox environment.

\section{PEROXISOME FUNCTION AND REDOX SIGNALING}


From the sections above, it is clear peroxisomes have the intrinsic ability to mediate and modulate redox-driven signaling events. Unfortunately, the mechanisms involved are poorly understood and have only recently begun to be characterized $(120,173)$. The primary reason for this was the rather limited toolbox for monitoring and manipulating peroxisomerelated redox processes. However, the continuous development of new and improved approaches for detecting redox-active compounds in a spatiotemporal manner in living cells has boosted the field and offers unprecedented possibilities for tracking redox-active species. In the following two sections, we first provide a short overview of the major tools and strategies that have been used to study the role of peroxisomes in cellular redox metabolism. Afterwards, we provide specific examples of cellular processes influenced by changes in peroxisomal redox metabolism. Importantly, as it is impossible to cover all tools and strategies developed to date, we limit ourselves to those that are directly relevant for studying the role of peroxisomes in cellular redox modifications and signaling (methods for detecting irreversible oxidative modifications are not discussed). Also, as this review is not intended to be a technical reference guide for the tools and strategies described, the reader is referred to other publications for technical details.

\section{Tools to monitor redox changes}

A first requirement for studying the potential role of specific cell organelles in cellular redox signaling is to have access to tools and methodologies that are suitable to monitor the levels of different ROS, the oxidation state of specific redox couples, and/or redox-related posttranslational modification in a spatiotemporal manner (Fig. 4). Most current approaches are based on fluorescent sensors (20) and (immuno)chemical detection of oxidative modifications (26). The former group includes (i) oxidation-sensitive chemicals that can penetrate living cells and are oxidized to fluorescent molecules (177), and (ii) genetically- 
encoded fluorescent redox sensors that can be easily directed to various subcellular locations by appending a compartment-specific targeting signal (151). Importantly, unlike most commonly used chemical redox probes, the ROS-related changes in the genetically-encoded sensors are fully reversible, thereby enabling dynamic real-time measurements (151). In addition, as these probes can be targeted to specific subcellular locations, they allow to look at redox state connectivity between different organelles (25).

\section{$G S H / G S S G$}

The glutathione redox couple (GSH/GSSG) is one of the main cellular defense mechanism against oxidative stress. Currently, one of the most popular probes for assessing the intracellular glutathione redox balance is roGFP2, a redox-sensitive variant of the enhanced green fluorescent protein (68). RoGFP2 contains two redox-active cysteines on adjacent surface-exposed $\beta$-strands close to the chromophore. Disulfide bond formation between these cysteine residues promotes protonation of the chromophore, thereby increasing its excitation peak near $400 \mathrm{~nm}$ at the expense of the peak near $480 \mathrm{~nm}$. The corresponding fluorescence intensity ratios (around 510) provide accurate insight into the redox environment of the chromophore (68). Importantly, the ratiometric readout of the probe is not influenced by ambient $\mathrm{pH}$ changes in the physiological range $(68,151)$. Intracellularly, roGFP2 predominantly equilibrates with the glutathione redox couple through the action of endogenous glutaredoxins (GRXs) (20). To facilitate this process, roGFP2 has been covalently fused to GRX1 (64). By employing targeted variants of roGFP2, we previously obtained evidence that (i) the intraperoxisomal redox environment can be modulated in response to changing environmental conditions or altered peroxisomal antioxidant enzyme levels $(75,168)$, (ii) the relative redox state of the peroxisome lumen compared to that of the cytosol is determined by the composition of the cell culture medium (75), (iii) peroxisomes within individual cells exhibit substantial heterogeneity in redox state (101), and (iv) loss in CAT activity (75), excess 
ROS production inside peroxisomes (174), or both acute and chronic inactivation of peroxisome biogenesis (134) increases the mitochondrial GSH/GSSG balance.

\section{General ROS}

One of the most widely used probes for detecting ROS in living cells is $2^{\prime}, 7^{\prime}$ dichlorodihydrofluorescein diacetate $\left(\mathrm{H}_{2}\right.$ DCFDA). $\mathrm{H}_{2}$ DCFDA is a cell-permeable dye which upon uptake is deacetylated to $\mathrm{H}_{2} \mathrm{DCF}$, a hydrophilic alcohol that in turn can be oxidized to the highly fluorescent 2',7'-dichlorofluorescein (DCF) (77). Within the field, this probe has already successfully been used to demonstrate that (i) cellular ROS levels are markedly increased in fibroblasts from hypocatalasemic individuals (178) and X-ALD patients (51), (ii) CAT overexpression in insulin-producing cells reduces palmitic acid-induced ROS generation (48), and (iii) an increase in peroxisome number with a concomitant increase in CAT activity prevents the amyloid- $\beta$-induced ROS increase in hippocampal neurons (146). In general, these observations support the view that peroxisomes, along with CAT activity, protect cells from oxidative stress. However, other studies have reported that, in comparison with control cells, DCF fluorescence is (i) less readily detectable in peroxisome-deficient CHO cells (180), and (ii) markedly increased in rat liver FAO cells treated for $1 \mathrm{~h}$ with the peroxisome proliferatoractivated receptor alpha (PPAR $\alpha)$ agonist clofibrate (186). The reasons for these apparently conflicting observations are unclear. The differences observed may be attributable to the use of different cell types, other culture conditions, and/or non-peroxisome-related redox changes (138). Indeed, regarding the latter observation, it is important to note that (i) upon treatment of rodent liver cells with PPAR $\alpha$ ligands, the onset of increased peroxisomal oxidase activity becomes only apparent after a lag period of 6-24 hours $(63,113)$, and (ii) such treatment only results in increased peroxisomal $\mathrm{H}_{2} \mathrm{O}_{2}$ levels in conditions where a suitable substrate is added to the cells (97). 
A second general ROS indicator is Redoxfluor, a fluorescence resonance energy transfer-based redox sensor consisting of a central cysteine-rich domain that is $\mathrm{N}$ - and Cterminally flanked by Cerulean and Citrine fluorescent proteins, respectively $(124,180)$. Upon oxidation, internal disulfide bond formation causes a conformational change leading to a decrease in the yellow-to-cyan emission ratio (180). Redoxfluor responds to various redoxrelated metabolites and, in cellulo, it mainly senses the redox potentials of glutathione and thioredoxin (124). Until now, this indicator has only been used to compare the redox state within peroxisomes and the cytosol in peroxisome-deficient and control $\mathrm{CHO}$ cells. These experiments revealed that, under the conditions employed, the intraperoxisomal environment is more reductive than the cytosol. In addition, it was also found that the cytosolic redox state of cell mutants lacking functional peroxisomes was more reductive than that of control cells $(180)$.

\section{Superoxide}

The most commonly used fluorogenic probe to detect intracellular $\mathrm{O}_{2}{ }^{-\bullet}$ is dihydroethidium (DHE). DHE is oxidized to 2-hydroxyethidium, a molecule that rapidly intercalates into double-stranded DNA, thereby staining the nucleus (92). DHE has already been successfully used to show that $\mathrm{O}_{2}{ }^{\bullet-}$ levels are markedly elevated in (i) cerebellar neurons from peroxisome-deficient mice (116), (ii) renal cortical sections from Pexl $1 \alpha^{-/}$mice, which have reduced abundance of functional peroxisomes (176), and (iii) FAO cells treated for $1 \mathrm{~h}$ with the PPAR $\alpha$ agonists WY-14643 (185) or clofibrate (186). Also here, the claim that a 1-h treatment of FAO cells with PPAR $\alpha$ agonists specifically alters peroxisomal redox metabolism can be questioned (see above).

\section{Hydrogen peroxide}


Hyper is the first genetically-encoded fluorescent biosensor capable of detecting physiological concentrations of $\mathrm{H}_{2} \mathrm{O}_{2}$ with high selectivity (16). This dual-excitation fluorescent probe consists of a circularly permutated fluorescent protein (e.g., cpYFP) that is inserted into the $\mathrm{H}_{2} \mathrm{O}_{2}$-sensitive regulatory domain of $E$. coli transcription regulator OxyR (20). Upon oxidation of Hyper, the sensor undergoes a conformational change that is subsequently transmitted to the fluorescent protein, thereby causing a pronounced increase in one of its excitation peaks at the expense of the other (16). A main disadvantage of the Hyper probes is their extreme $\mathrm{pH}$ sensitivity and, therefore, possible $\mathrm{pH}$ changes should be carefully monitored (141). By employing different organelle-targeted variants of Hyper, it has been shown that the toxicity of excess long-chain fatty acids in insulin-producing $\beta$-cells is mediated by peroxisome-generated $\mathrm{H}_{2} \mathrm{O}_{2}$ (48).

Another dual-excitation ratiometric fluorescent $\mathrm{H}_{2} \mathrm{O}_{2}$ indicator gaining in popularity is roGFP2-ORP1 (65). ORP1 is a yeast thiol peroxidase that is extremely $\mathrm{H}_{2} \mathrm{O}_{2}$-sensitive. Upon oxidation, the peroxidase can participate in thiol-disulfide exchange reactions with other cellular proteins (20) and, in the roGFP2-ORP1 fusion, it promotes near-stoichiometric oxidation of roGFP2 (see above) (65). We have recently observed that a peroxisome-targeted variant of this sensor is almost completely oxidized in some (e.g., human embryonic kidney cells 293 (HEK-293)), but not all (e.g., human fibroblasts) cell lines tested (102). By employing cytosolic roGFP2-ORP1, we could obtain evidence that (i) peroxisome-derived $\mathrm{H}_{2} \mathrm{O}_{2}$ has the potential to modulate the oxidation state of redox-sensitive protein thiols in the cytosol, and (ii) the response profile of cytosolic roGFP2-ORP1 to peroxisome-derived $\mathrm{H}_{2} \mathrm{O}_{2}$ is inversely correlated to CAT activity and cellular GSH content (102).

\section{Oxidative cysteine modifications}


A common mechanism for redox signaling is the reversible modification of cysteines. As the thiol moiety of cysteine can undergo a vast array of posttranslational modifications (Fig. 1), many different methods have been developed to study cysteine modifications in intact cells (142). Most of these techniques monitor the global protein thiol state by using functionalized cysteine-labeling reagents based on the selectivity of maleimides and iodoacetamides toward thiols. Others use speed of migration on non-reducing SDS-PAGE to monitor inter- and intraprotein disulfide bond formation. To determine the identity of the proteins and cysteine residues modified, these procedures are often coupled to specific enrichment strategies and mass spectrometry (142). Currently, only a handful of studies have investigated the direct relationship between mammalian peroxisomal metabolism and intracellular thiol redox equilibrium. One study has demonstrated that CAT inhibition in Chang liver cells markedly increased global protein disulfide levels (179). Another study has shown that CAT overexpression diminished cysteine oxidation of cardiac mitochondrial proteins in transgenic mice (181). Furthermore, large-scale proteomics analyses of several mouse tissues have revealed that multiple peroxisomal proteins, including CAT, are S-nitrosated (47). Finally, we recently obtained evidence that some cytoplasmic proteins (e.g., RELA, NFKB1, PTEN, and FOXO3) known to undergo reversible thiol modifications in response to mitochondrial $\mathrm{H}_{2} \mathrm{O}_{2}$ production (152) can also be modified by peroxisome-derived $\mathrm{H}_{2} \mathrm{O}_{2}(102)$. The physiological significance of most of these observations remains to be determined.

\section{Strategies to modulate redox balance}

A second requirement for studying the potential role of specific cell organelles in redox signaling is to have access to methods and tools that can be used to modulate their ROS fluxes (Fig. 4). Strategies that have been successfully implemented in the peroxisome field include (i) pharmacological regulation of peroxisome abundance, (ii) metabolic regulation of peroxisomal 
$\beta$-oxidation, and (iii) inhibition or enhancement of peroxisomal pro- or antioxidant enzyme activities. In the following sections, the advantages and disadvantages of these strategies will be discussed.

\section{Pharmacological regulation of peroxisome abundance}

Peroxisomes are dynamic organelles that continuously change their number, enzyme content, and metabolic functions in response to changes in nutrient conditions and xenobiotic stimuli (53). Previous studies have shown that many of these adaptations can be observed upon treatment of cells with PPAR agonists or histone deacetylase (HDAC) inhibitors (49). PPARs (PPAR $\alpha, \operatorname{PPAR} \gamma$, and PPAR $\delta$ ) are ligand-activated transcriptional regulators of genes controlling a variety of physiological processes (e.g., lipid metabolism, energy homeostasis, and inflammation) $(83,138)$, and important natural and synthetic PPAR agonists include among others - specific fatty acids (e.g., dietary lipids and their metabolites), fibrates (e.g., clofibrate and fenofibrate) and thiazolidinediones (e.g., rosiglitazone and pioglitazone) (13). HDACs catalyze the removal of acetyl groups on histones (and other proteins), thereby controlling chromatin remodeling and transcriptional activation (33).

PPAR agonists have already been used for a long time to induce peroxisome biogenesis and fatty acid $\beta$-oxidation in a variety of rodent tissues (e.g., liver) and cell types (e.g., $\beta$-cells, pre-adipocytes, hypothalamic neurons) $(45,71,103,149)$. However, long-term administration is known to lead to disproportionate increases in the activity of $\mathrm{H}_{2} \mathrm{O}_{2}$-generating enzymes and CAT, and this imbalance has been linked to oxidative stress-induced DNA damage and tumor development $(78,182)$. Importantly, human cells appear to be less responsive, displaying minimal peroxisome proliferation following exposure to PPAR activators (149). However, over the past decades, evidence has accumulated that peroxisome activity can be upregulated in a variety of human, mouse, and rat cells through administration of HDAC inhibitors, such 
as 4-phenylbutyrate and suberoylanilide hydroxamic acid (49). For example, 4-phenylbutyrate has been shown to significantly increase peroxisome number and peroxisomal $\beta$-oxidation in rat liver, primary rat hepatocytes and glial cell cultures, and cells from X-ALD patients and $A b c d 1^{-/-}$mice $(18,82)$.

In summary, these observations clearly demonstrate that PPAR agonists and HDAC inhibitors can be used to drive peroxisome proliferation. However, note that this pharmacological approach suffers from multiple intrinsic limitations. First, the ligandresponsiveness of PPARs is species- and tissue-specific (149). Second, as PPARs and HDACs play a pleiotropic role in many physiological processes $(33,83)$, it may be difficult to directly link specific observations to the increase in peroxisome number. Finally, a disproportionate increase in the activity of $\mathrm{H}_{2} \mathrm{O}_{2}$-generating enzymes and CAT leads only to an increase in peroxisome-derived $\mathrm{H}_{2} \mathrm{O}_{2}$ production when the cells are cultured in the presence of a suitable substrate.

\section{Metabolic regulation of peroxisomal $\beta$-oxidation}

Currently, it is well-known that incubation of cells with carboxylates (or their precursors) that can be desaturated by peroxisomal acyl-CoA oxidases significantly enhance the peroxisomal production of $\mathrm{H}_{2} \mathrm{O}_{2}$ (164). The validness of this method has been confirmed in different systems (e.g., cells, perfused organs, and intact animals) and with different types of carboxylates (100; and references therein). Importantly, although at first sight very attractive, also this approach suffers from two intrinsic limitations: (i) as carboxylic acid

substrates first need to be activated through thioester formation with coenzyme A (CoA), incubation of cells with $\beta$-oxidizable peroxisomal substrates does not only lead to an increase in $\mathrm{H}_{2} \mathrm{O}_{2}$ production, but also to a lowering of cellular (cytosolic) CoA, a widespread non- 
protein thiol (24); and (ii) exposure of cells to free fatty acids induces cellular oxidative stress in a manner non-specific to peroxisomal metabolism $(39,81)$.

\section{Inhibition or enhancement of pro- or antioxidant enzyme activities}

Another frequently used strategy to modulate peroxisomal redox metabolism is to interfere with the pro- or antioxidant activity of the organelle. This can be realized by the use of chemical agents or (patient) cell lines in which specific pro- or antioxidant enzymes are transiently or persistently elevated or decreased. The most classic method for interfering with peroxisomal $\mathrm{H}_{2} \mathrm{O}_{2}$ metabolism is to incubate cells with 3-amino-1,2,4 triazole (3-AT), a compound that inhibits CAT activity irreversibly through a $\mathrm{H}_{2} \mathrm{O}_{2}$-dependent suicide mechanism (109). Alternative strategies to modulate CAT activity include (i) the use of cells from patients (61) or mice (73) with reduced or no CAT activity, (ii) transient or stable overexpression of CAT $(28,145,150)$, or (iii) exposure of cells to CAT-SKL, a recombinant CAT analog designed to enter cells and more efficiently localize in peroxisomes (see below). Major advantages of 3-AT are that it is widely applicable and inhibits CAT activity in a dosedependent manner (143). However, long-term treatment may lead to adaptive responses (143). The same is true for organisms and cell lines in which the expression levels of CAT have been stably altered $(2,23)$. On the other hand, as CAT is targeted to peroxisomes by a non-canonical PTS1 (-KANL) (137) that interacts with PEX5 less efficiently than the normal PTS1 (-SKL) $(88,119)$, transient overexpression may result in a partial mislocalization of the newlysynthesized protein, thereby complicating the interpretation of the results. To overcome this potential problem and to have access to a CAT biologic that is universally applicable to all cell types, Terlecky and colleagues designed and validated CAT-SKL, a fully functional enzyme containing an N-terminal poly-arginine cell-penetrating peptide (to facilitate cellular uptake) and a strong C-terminal PTS (to enhance peroxisomal import) (88). Other antioxidant enzymes whose expression levels have been upregulated within peroxisomes include superoxide 
dismutase 1 (SOD1), glutathione S-transferase kappa 1 (GSTK1), and PRDX5: transient overexpression of peroxisome-targeted variants of SOD1 or GSTK1 protect mouse embryonic fibroblasts against excessive amounts of locally-produced $\mathrm{O}_{2}{ }^{\bullet-}$ and lipid hydroperoxides (LOOH), respectively (174); and stable expression of peroxisome-targeted PRDX5 in murine oligodendrocyte $158 \mathrm{~N}$ cells provides cytoprotective effects against locally produced LOOH and moderate concentrations of exogenously applied $\mathrm{H}_{2} \mathrm{O}_{2}$ (168).

To date, three different approaches have been used to selectively increase peroxisomal ROS production by overexpression (and activation) of pro-oxidant enzymes. First, different studies have overexpressed ACOX1 in different mammalian cell types (e.g., COS-1, normal African green monkey kidney cells, rate urothelial cells) and exposed these cells to linoleic acid, a substrate for peroxisomal $\beta$-oxidation $(36,97,123)$. From these experiments, it was evident that sustained overexpression of ACOX1 can activate NF- $\mathrm{B}$ (97) and cause cell transformation $(36,125)$ in a substrate-dependent manner. Second, we have employed peroxisome-targeted KillerRed to study the downstream effects of peroxisome-derived ROS in mouse embryonic fibroblasts (174) and murine $158 \mathrm{~N}$ cells (168). As KillerRed is a red fluorescent photosensitizer that efficiently generates $\mathrm{O}_{2}{ }^{\bullet-}$ upon green light illumination, targeted variants of this protein are powerful tools for dissecting the downstream effects of local ROS production in an optogenetically-controlled manner (29). Third, we have developed a D-amino acid oxidase (DAO)-based approach to selectively generate $\mathrm{H}_{2} \mathrm{O}_{2}$ inside peroxisomes in a D-amino acid concentration-dependent manner in HEK-293 cells (102). By employing this cell line, we could demonstrate that peroxisome-derived $\mathrm{H}_{2} \mathrm{O}_{2}$ can oxidize redox-sensitive cysteines in multiple endogenous proteins (102).

\section{Peroxisomes as redox signaling hubs}


Numerous cellular processes are regulated by intracellular ROS levels (100). For example, at low levels, ROS increase cell proliferation and survival through homeostatic signaling (e.g., through posttranslational oxidative modifications); at moderate levels, ROS promote the expression of stress-responsive genes (e.g., NF-kB, FOXO, NRF2) which mediate stress tolerance; and at high levels, ROS cause damage to macromolecules, thereby triggering senescence or cell death (Fig. 2) $(30,148)$. Given that peroxisomes have the intrinsic ability to modulate the cellular redox state (see above), it may not come as a surprise that these organelles are currently emerging as redox signaling platforms (Fig. 5). In the following sections, we review evidence supporting this claim.

\section{Gene expression}

Almost two decades ago, ACOX1 overexpression in COS-1 cells in the presence of a $\mathrm{H}_{2} \mathrm{O}_{2}$-generating substrate was found to activate an NF- $\kappa$ B-regulated reporter gene (97). In line with this observation, another study recently found that also 3-AT-mediated inhibition of CAT resulted in NF- $\mathrm{BB}$ activation in human differentiated adipocytes (143). In addition, such treatment resulted in reduced gene expression levels of - among others - multiple antioxidant enzymes (e.g., GPX4, PRDX1, PRDX3, PRDX5), the stress-responsive transcription factors NRF2 and FOXO1, and the ligand-activated transcription factor PPAR $\gamma$ (143). Furthermore, by employing genome-wide RNA sequence analysis, another study demonstrated that 1102 and 1351 transcripts are up- and down-regulated, respectively, in livers of $\mathrm{Cat}^{-/-}$mice (70). Interestingly, unlike what was observed in human differentiated adipocytes (143), liver transcripts for GPXs and PRDXs were unchanged and even elevated for PPAR $\gamma$ (70). In summary, these observations clearly demonstrate that alterations in peroxisomal $\mathrm{H}_{2} \mathrm{O}_{2}$ metabolism do modulate gene expression. The biological significance of these findings remains to be investigated. 


\section{Cell proliferation and differentiation}

Although it is well-established that low $\mathrm{H}_{2} \mathrm{O}_{2}$ levels promote cell proliferation and differentiation (66), little is known about how alterations in peroxisomal redox metabolism influence these processes. A few studies carried out on human vascular smooth muscle cells (28) and mouse aortic endothelial cells (26) have demonstrated that CAT overexpression prolonged the doubling time of these cells, and that incubation with 3-AT could prevent this diminished growth rate. Interestingly, the CAT overexpression-induced proliferation defect could be linked to an extended $\mathrm{G}_{0} / \mathrm{G}_{1}$ phase (26) and increased apoptosis (28). Other studies have focused on the role of CAT overexpression in cancer cells. In line with the previous findings $(28,127)$, these studies demonstrated that CAT overexpression in the human breast cancer cell line MCF-7 (59) and human A375 amelanotic melanoma cells (23) down-regulated cell proliferation, as compared to the parental cell lines. In addition, depending on the melanoma clone that was analyzed, CAT overexpression also promoted cell migration or melanocyte differentiation (23). To the best of our knowledge, there are currently no other reports documenting the relationship between peroxisomal redox metabolism and cell differentiation in mammals.

\section{Senescence and cell death}

Cellular senescence is a process in which metabolically-active cells cease dividing and undergo distinctive phenotypic alterations (e.g., increased levels of DNA damage, a decrease in mitochondrial membrane potential) in response to various stressors (35). Over the years, it has become apparent that CAT is progressively mislocalized to the cytosol as cells age and approach replicative senescence (58). In addition, also peroxisome number is altered, and the organelles accumulate PEX5 on their membranes (94). Given that (i) cellular aging has been associated with chronic increases in redox state (115), (ii) increases in cellular redox state have 
been reported to interfere with PEX5 monoubiquitination and recycling (8), (iii) a reduction in the cycling kinetics of PEX5 mainly results in the mislocalization of peroxisomal proteins containing a weak PTS1 (e.g., CAT) (94), and (iv) monoubiquitination of PEX5 has been linked to peroxisome degradation (121), it is tempting to speculate that the peroxisome-related observations are secondary effects of senescence. However, given that CAT-SKL delays the appearance of senescence markers in aging cells (94), disturbances in peroxisomal redox metabolism may also actively contribute to the cellular aging phenotypes.

Currently, there is ample evidence that disturbances in peroxisomal redox metabolism sensitize cells to cell death induced by multiple stimuli. For example, it has been reported that (i) saturated non-esterified fatty acid-induced lipotoxicity in rat insulin-producing cells is caused by the combined effect of increased peroxisomal $\mathrm{H}_{2} \mathrm{O}_{2}$ production and the intrinsically low CAT activity in these cells $(48,57)$, (ii) CAT overexpression in pancreatic $\beta$-cells sensitizes non-obese diabetic mice to cyclophosphamide-induced $\beta$-cell destruction (96), (iii) overexpression of CAT sensitizes murine hepatocytes and fibroblasts to TNF $\alpha$-, $\gamma$-irradiation, and paraquat-induced cell death (34), and (iv) human and mouse fibroblasts lacking functional peroxisomes are more sensitive to KillerRed-induced oxidative stress than control cells (174). Importantly, the exact molecular mechanisms underlying these phenomena remain largely unknown and are likely to vary depending on the type, dosage, duration, and site of ROS production. Here it is worthwhile to mention that we have shown that photoactivation of peroxisomal KillerRed triggers signaling events that perturb the mitochondrial redox balance (75) and ultimately result in the activation of mitochondrial cell death pathways $(168,174)$. Combined with the observations that a reduction in CAT activity contributes to oxidative stress-dependent mitochondrial dysfunction $(75,89,171)$, these findings foster the idea that mitochondria can act as dynamic receivers, integrators, and transmitters of peroxisome-derived oxidative stress (174). 


\section{Autophagy}

Currently, there is a general consensus that mammalian peroxisomes are mainly degraded by the autophagy-lysosome pathway, in a process known as pexophagy (122). As dysfunctional peroxisomes may disturb cellular redox balance $(37,55)$ and autophagy is a redox-regulated process (147), an intriguing question is how disturbances in peroxisomal redox metabolism affect pexophagy.

A recent study has shown that both exposure of human liver carcinoma cells (HepG2) to $0.4 \mathrm{mM} \mathrm{H} \mathrm{H}_{2} \mathrm{O}_{2}$ and treatment of FAO cells with the PPAR $\alpha$-agonist clofibrate selectively induces pexophagy through a mechanism involving the PEX5-mediated recruitment of ATM to the PO membrane, where the kinase is subsequently activated in response to ROS and induces autophagy through AMPK-TSC2-mediated mTORC1 suppression (186). On the other hand, by employing our DAO-based approach to selectively generate $\mathrm{H}_{2} \mathrm{O}_{2}$ inside peroxisomes, we have found that peroxisomes that produce sufficient quantities of $\mathrm{H}_{2} \mathrm{O}_{2}$ to modulate cellular redox state are not necessarily degraded (102). Whether these apparently conflicting observations reflect cell type-specific responses or methodological differences, remains to be determined. In this context, it is pertinent to consider that (i) intracellular and extracellular $\mathrm{H}_{2} \mathrm{O}_{2}$ perturbations are known to elicit different physiological responses (98), (ii) the effect of PPAR ligands on cellular redox state cannot simply be reduced to an increase in peroxisomal $\mathrm{H}_{2} \mathrm{O}_{2}$ production (133), (iii) PPAR $\alpha$ agonists are considered to increase (and not to decrease) peroxisome number in rodent liver (182), and (iv) others have reported that ATM activation by extranuclear ROS in HepG2 cells does not require peroxisomes, but mitochondria (114).

\section{Energy metabolism}

Studies in mice have linked peroxisomal ROS metabolism to food intake, a process controlled by the hypothalamic leptin-melanocortin pathway (45). Specifically, it was shown 
that (i) high-fat diet feeding induces PPAR $\gamma$ expression and peroxisome proliferation in proopiomelanocortin (POMC) neurons, (ii) peroxisome proliferation in POMC neurons (e.g., in response to rosiglitazone) decreases ROS levels and increases food intake in lean mice on high fat diet, and (iii) suppression of peroxisome proliferation in these cells (e.g., by treatment with the PPAR $\gamma$ antagonist GW9662) increases ROS levels and decreases food intake in dietinduced obesity animals (45). Based on these findings, it was hypothesized that, during times of overnutrition, high steady-state ROS levels may induce peroxisome proliferation to prevent POMC neurons from damage and modulate their neuronal activity (44).

\section{Inflammation}

As high ROS levels drive signaling processes promoting inflammation (148), it may not surprise that also peroxisomes have garnered increasing attention as signaling platforms that modulate inflammation. For example, it has been demonstrated that (i) defects in peroxisome biogenesis, peroxisomal $\beta$-oxidation, or CAT activity increase pro-inflammatory cytokine production $(143,157)$ and stimulate maladaptive processes such as neuroinflammation (21) and fibrosis (128), (ii) PPAR $\alpha$ agonist-induced peroxisome proliferation in cortical neurons (62) and CAT-SKL treatment of primary skin fibroblasts (183) protect these cells from inflammatory damage, and (iii) high CAT activity in human alveolar macrophages limits the effectiveness of $\mathrm{H}_{2} \mathrm{O}_{2}$ to act as a mediator of inflammatory gene expression (31). The molecular mechanisms underlying most of these observations are yet to be unraveled.

\section{PEROXISOMAL REDOX DYSFUNCTION AND DISEASE}

Throughout the years, accumulating evidence has suggested that derangements in peroxisomal redox metabolism can contribute to various oxidative stress-related disorders (Fig. 6). The following sections provide a concise overview of our current knowledge on this topic. 


\section{Cancer}

The oldest and best known example that alterations in peroxisomal redox metabolism can be associated with cancer development is the observation that prolonged treatment of mice and rats with PPAR $\alpha$ agonists causes hepatocellular carcinomas $(112,139)$. Another example is that CAT activity is strongly decreased in renal (56), colon (91), breast (4), and skin (154) cancers. The molecular mechanisms underlying these phenomena remain to be established. However, here it is worthwhile to note that peroxisome abundance in human clear cell renal cell carcinomas appears to be correlated with the expression levels of hypoxia-inducible factor $2 \alpha$, a negative regulator of peroxisome abundance and metabolism (170). Lastly, peroxisomal branched-chain fatty acid $\beta$-oxidation appears to be selectively upregulated in human prostate cancer tissue and some prostate cancer cell lines (184), and malignant transformation of prostate cells is associated with a peroxisomal localization of MCT2, a high affinity pyruvate/lactate transporter that may be involved in the transfer of reducing equivalents from peroxisomes to the cytosol (162). Given that metabolic reprogramming is one of the typical hallmarks of cancer development and progression (27), these findings suggest that alterations in peroxisome number and redox metabolism may elicit metabolic features that provide unique advantages for malignant transformation and tumor growth.

\section{Diabetes}

Diabetes is a multifactorial disorder caused by a combination of genetic, epigenetic, and environmental factors (79). Several studies have provided evidence for a tight link between disturbances in peroxisomal redox metabolism and diabetes. For example, it has been demonstrated that endogenous CAT protects kidneys from streptozotocin-induced diabetic mice against oxidative stress through maintaining peroxisomal function and mitochondrial fitness (74). In addition, it has been reported that $\mathrm{Cat}^{-/}$mice develop an obese pre-diabetic 
phenotype (e.g., impaired glucose tolerance, increased fasting serum insulin levels) (70) and that patients with acatalasemia have an increased risk of developing diabetes (61). On the other hand, induction of experimental diabetes in mice has been shown to decrease CAT activity in kidney (43) and to increase peroxisomal $\beta$-oxidation in kidney (43) and liver (161). The effect on liver peroxisomes was ascribed to the increased supply of fatty acids to the liver in the diabetic state and to increased oxidative stress (161). Finally, PPAR $\alpha$ agonist-induced increase in peroxisomal $\beta$-oxidation has been shown to protect rat pancreatic $\beta$-cells against palmitate toxicity (71). How this observation can be reconciled with the finding that peroxisomegenerated $\mathrm{H}_{2} \mathrm{O}_{2}$ functions as an important mediator of lipotoxicity in insulin-producing cells (48), remains to be determined.

\section{Aging}

As disturbances in peroxisomal redox metabolism are likely to contribute to cellular senescence (see above) and senescence has been causally implicated in generating age-related phenotypes (12), peroxisomes are also positioned to modulate longevity. However, compelling evidence to support this claim is still lacking in humans. Nevertheless, note that lack of peroxisomal CAT causes a progeric phenotype in Caenorhabditis elegans (135) and functional peroxisomes are important factors in yeast chronological aging (93).

\section{Neurodegeneration}

As already extensively explained above, genetic defects in peroxisome function often cause mitochondrial dysfunction and oxidative stress, which in turn contributes to neuronal cell death $(38,51,104,160)$. However, peroxisomes may also modulate progression of other neurodegenerative diseases $(37,55)$. For example, peroxisome proliferation and CAT-SKL can protect rat hippocampal neurons from $\beta$-amyloid neurodegeneration through ROS level reduction $(58,58,146)$. In addition, cells from patients with hereditary spastic paraplegia, a 
pathological condition leading to progressive spasticity and gait abnormalities, display (i) altered intracellular distributions of peroxisomes and mitochondria, (ii) decreased microtubuledependent peroxisome transport, and (iii) increased oxidative stress and $\mathrm{H}_{2} \mathrm{O}_{2}$ sensitivity (3, 169).

\section{Ischemia-reperfusion injury}

Over the past decades, it has become clear that peroxisomes play a pivotal role in renal, myocardial, and cerebral ischemia-reperfusion injury $(99,111,166$; and references therein). Most of these studies conclude that peroxisome activity protects tissues and cells against hypoxia-reoxygenation- and ischemia-reperfusion-induced oxidative damage. On one hand, this protection has been attributed to the organelle's antioxidant activities $(69,166)$. On the other hand, it has been suggested that peroxisomal $\beta$-oxidation may protect mitochondria from the toxic effects of fatty acids released from phospholipids during myocardial ischemia (99, 136).

\section{Hearing loss}

Deficiencies in DFNB59, also called pejvakin (PJVK), have been associated with sensorineural hearing loss (42). Several years ago, it was demonstrated that PJVK is a peroxisomal protein and that cochlear sensory hair cells and auditory pathway neurons of Pjvk/- mice and patients are hypervulnerable to noise (41). Further mechanistic studies revealed that (i) sound exposure rapidly upregulates PJVK expression in cochlear sensory hair cells and auditory pathway neurons of control mice, (ii) increased PJVK levels trigger peroxisome proliferation, and (iii) $\mathrm{Pj}_{\mathrm{N}} \mathrm{k}^{-/}$cochleas display impaired adaptive peroxisome proliferation and redox balance in response to noise (41). Taken together, these findings pointed to a role for peroxisomes as antidote to noise-induced hearing loss $(41,107)$. However, as another recent study reported that PJVK binds to and co-localizes with TRIOBP, a cytoskeleton-associated 
protein mutated in human hereditary deafness DFNB28 (85), at stereocilia rootlets of cochlear hair cells (80), this issue deserves further investigation.

\section{Kwashiorkor}

Kwashiorkor, a disease caused by protein deficiency, has been associated with multiple adverse effects including - among others - hepatic steatosis, an almost total absence of peroxisomes, mitochondrial dysfunction, and oxidative stress $(46,50,106,126)$. Recently, it was reported that feeding weanling rats a low protein diet yielded a similar phenotype, and that treating these animals with fenofibrate resulted in peroxisome reappearance, restoration of mitochondrial fitness, and amelioration of the hepatic phenotype (165). Taken together, these findings demonstrate that diet-induced depletion of peroxisomes sensitizes cells to mitochondrial oxidative stress, thereby directly contributing to the pathogenesis of kwashiorkor.

\section{KEY RESEARCH QUESTIONS, CHALLENGES, AND PROSPECTS}

As reviewed here, a growing body of evidence indicates that peroxisomes have the intrinsic ability to mediate and modulate redox-driven signaling events. Plenty of arguments have been presented to support the view that - depending on the organism, cell type, physiological state, and/or type of stressor - these organelles may function as a source or sink of ROS, and $\mathrm{H}_{2} \mathrm{O}_{2}$ in particular. In addition, it is clear that peroxisomes harbor sophisticated redox control mechanisms that integrate environmental cues and influence multiple physiological and metabolic functions. However, the molecular details underpinning these events are only just beginning to emerge.

Several fundamental questions need to be addressed to advance our understanding of how peroxisomes serve as intracellular redox signaling platform. A first intriguing question is how various redox species (e.g., $\mathrm{H}_{2} \mathrm{O}_{2}$, GSH, GSSG, $\mathrm{NAD}^{+}$, and NADH) are transported across 
the peroxisomal membrane. Currently, it is assumed that (i) small molecules such as $\mathrm{H}_{2} \mathrm{O}_{2}$, GSH and ascorbic acid can freely penetrate the peroxisomal membrane through PXMP2, a nonselective pore-forming protein with an upper molecular size limit of 300-600 Da (140), and (ii) the redox equivalents of NADH, generated by peroxisomal $\beta$-oxidation, are transferred across the peroxisomal membrane via a lactate/pyruvate-based redox shuttle $(14,110)$. However, unambiguous experimental evidence in support of these concepts is still lacking. A related question is how peroxisomes regulate their GSH/GSSG and $\mathrm{NAD}^{+} / \mathrm{NADH}$ pools to maintain redox homeostasis and keep peroxisomal $\beta$-oxidation going.

A second key research question concerns the molecular targets of peroxisome-derived $\mathrm{H}_{2} \mathrm{O}_{2}$. Indeed, by studying a preselected group of proteins of interest, we recently showed that peroxisome-derived $\mathrm{H}_{2} \mathrm{O}_{2}$ can oxidize redox-sensitive cysteines in multiple endogenous proteins within and outside peroxisomes (102). However, to gain meaningful insight into how changes in peroxisomal metabolism modulate intracellular $\mathrm{H}_{2} \mathrm{O}_{2}$ signaling networks, it is essential to conduct similar studies using unbiased proteomic approaches.

A third important question concerns the mechanism by which peroxisome-derived $\mathrm{H}_{2} \mathrm{O}_{2}$ participates in cellular redox signaling. On one hand, the oxidant may directly react with redoxsensitive protein thiols in its proximity. Alternatively, the transmission of oxidizing equivalents may occur through a disulfide relay pathway, in which $\mathrm{H}_{2} \mathrm{O}_{2}$-scavenging enzymes (e.g., peroxiredoxins $(86,118))$ are first oxidized and subsequently transmit the oxidizing equivalents to downstream proteins via thiol-disulfide interchange reactions (167). In case the second mechanism is favored, CAT and PRDX5 may play non-overlapping roles in $\mathrm{H}_{2} \mathrm{O}_{2}$ scavenging. Also, as biological membranes may constitute a permeability barrier for $\mathrm{H}_{2} \mathrm{O}_{2}(9,19)$, it can be expected that $\mathrm{H}_{2} \mathrm{O}_{2}$ concentration gradients will be formed, and this may affect the signaling mechanisms involved. Finally, a related but challenging task will be to gain more insight into 
the positive and negative feedback mechanisms that govern cellular responses to peroxisomederived $\mathrm{H}_{2} \mathrm{O}_{2}$.

Over the past decades, much has been learned about how peroxisomes participate in cellular redox metabolism. Multiple pro- and antioxidant systems have been identified, new tools for monitoring and manipulating the peroxisomal redox balance in cellulo have been developed, and peroxisomal redox metabolism dysfunction has been recognized as a potential contributor to multiple diseases. Future efforts are certain to expand on how peroxisomes are integrated into cellular redox signaling networks. As, at present, it is still unclear to what extent and through which mechanisms defects in peroxisomal redox metabolism contribute to cellular and organismal pathologies, such studies will provide important clues to understanding the role of peroxisomes in health and disease.

\section{ACKNOWLEDGMENTS}

MF is supported by grants from the KU Leuven (OT/14/100) and the Fonds voor Wetenschappelijk Onderzoek-Vlaanderen (Onderzoeksproject G095315N).

\section{AUTHOR DISCLOSURE STATEMENT}

No competing financial interests exist. 


\section{Abbreviations Used}

3-AT = 3-amino-1,2,4-triazole

ACOX1 = acyl-CoA oxidase 1

$\mathrm{ATM}=$ ataxia telangiectasia mutated

$\mathrm{CAT}=$ catalase

$\mathrm{CHO}=$ Chinese hamster ovary

$\mathrm{CoA}=$ coenzyme $\mathrm{A}$

COS-1 = SV40 large T-antigen-transformed African green monkey kidney cells

$\mathrm{DAO}=$ D-amino acid oxidase

$\mathrm{DHE}=$ dihydroethidium

$\mathrm{FOXO}=$ forkhead box $\mathrm{O}$

GRX $=$ glutaredoxin

$\mathrm{GSH}=$ reduced glutathione

$\mathrm{GSSG}=$ oxidized glutathione

GSTK1 = glutathione S-transferase kappa 1

$\mathrm{HDAC}=$ histone deacetylase

$\mathrm{NFKB} 1=$ nuclear factor kappa B subunit 1

NOS2 $=$ nitric oxide synthase

ORP $1=$ oxidant receptor peroxidase 1

$\mathrm{PEX}=$ peroxin (protein involved in peroxisome biogenesis)

$\mathrm{POMC}=$ pro-opiomelanocortin

PPAR $=$ peroxisome proliferator-activated receptor

$\operatorname{PRDX}=$ peroxiredoxin

PTEN $=$ phosphatase and tensin homolog

PTS1 = C-terminal peroxisomal targeting signal 
RELA = nuclear factor kappa B subunit RELA proto-oncogene

roGFP2 $=$ redox-sensitive variant of the enhanced green fluorescent protein

$\mathrm{RNS}=$ reactive nitrogen species

ROS $=$ reactive oxygen species

$\mathrm{SOD}=$ superoxide dismutase

$\mathrm{Ub}=$ ubiquitin

$\mathrm{X}-\mathrm{ALD}=\mathrm{X}$-linked adrenoleukodystrophy 


\section{References}

1. Ahmad S, Khan H, Shahab U, Rehman S, Rafi Z, Khan MY, Ansari A, Siddiqui Z, Ashraf JM, Abdullah SM, Habib S, and Uddin M. Protein oxidation: an overview of metabolism of sulphur containing amino acid, cysteine. Front Biosci 9: 71-87, 2017.

2. Abdo S, Shi Y, Otoukesh A, Ghosh A, Lo CS, Chenier I, Filep JG, Ingelfinger JR, Zhang SL, and Chan JS. Catalase overexpression prevents nuclear factor erythroid 2-related factor 2 stimulation of renal angiotensinogen gene expression, hypertension, and kidney injury in diabetic mice. Diabetes 63: 3483-3493, 2014.

3. Abrahamsen G, Fan Y, Matigian N, Wali G, Bellette B, Sutharsan R, Raju J, Wood SA, Veivers D, Sue CM, and Mackay-Sim A. A patient-derived stem cell model of hereditary spastic paraplegia with SPAST mutations. Dis Model Mech 6: 489-502, 2013.

4. Ahn J, Nowell S, McCann SE, Yu J, Carter L, Lang NP, Kadlubar FF, Ratnasinghe LD, and Ambrosone CB. Associations between catalase phenotype and genotype: modification by epidemiologic factors. Cancer Epidemiol Biomarkers Prev 15: 1217-1222, 2006.

5. Angelova PR and Abramov AY. Functional role of mitochondrial reactive oxygen species in physiology. Free Radic Biol Med 100: 81-85, 2016.

6. Antonenkov VD, Grunau S, Ohlmeier S, and Hiltunen JK. Peroxisomes are oxidative organelles. Antioxid Redox Signal 13: 525-537, 2010.

7. Antunes $\mathrm{F}$ and Cadenas E. Estimation of $\mathrm{H}_{2} \mathrm{O}_{2}$ gradients across biomembranes. FEBS Lett 475: 121-126, 2000.

8. Apanasets O, Grou CP, Van Veldhoven PP, Brees C, Wang B, Nordgren M, Dodt G, Azevedo JE, and Fransen M. PEX5, the shuttling import receptor for peroxisomal matrix proteins, is a redox-sensitive protein. Traffic 15: 94-103, 2014.

9. Appenzeller-Herzog C, Bánhegyi G, Bogeski I, Davies KJ, Delaunay-Moisan A, Forman HJ, Görlach A, Kietzmann T, Laurindo F, Margittai E, Meyer AJ, Riemer J, Rützler M, 
Simmen T, Sitia R, Toledano MB, and Touw IP. Transit of $\mathrm{H}_{2} \mathrm{O}_{2}$ across the endoplasmic reticulum membrane is not sluggish. Free Radic Biol Med 94: 157-160, 2016.

10. Avshalumov MV, Bao L, Patel JC, and Rice $\mathrm{ME} . \mathrm{H}_{2} \mathrm{O}_{2}$ signaling in the nigrostriatal dopamine pathway via ATP-sensitive potassium channels: issues and answers. Antioxid Redox Signal 9: 219-231, 2007.

11. Auten RL and Davis JM. Oxygen toxicity and reactive oxygen species: the devil is in the details. Pediatr Res 66: 141-127, 2009.

12. Baker DJ, Wijshake T, Tchkonia T, LeBrasseur NK, Childs BG, van de Sluis B, Kirkland JL, and van Deursen JM. Clearance of p16Ink4a-positive senescent cells delays ageingassociated disorders. Nature 249: 232-236, 2011.

13. Barlaka E, Galatou E, Mellidis K, Ravingerova T, and Lazou A. Role of pleiotropic properties of peroxisome proliferator-activated receptors in the heart: focus on the nonmetabolic effects in cardiac protection. Cardiovasc Ther 34: 37-48, 2016.

14. Baumgart E, Fahimi HD, Stich A, and Völkl A. L-lactate dehydrogenase A4- and A3B isoforms are bona fide peroxisomal enzymes in rat liver. Evidence for involvement in intraperoxisomal NADH reoxidation. J Biol Chem 271: 3849-3855, 1996.

15. Baumgart E, Vanhorebeek I, Grabenbauer M, Borgers M, Declercq PE, Fahimi HD, and Baes M. Mitochondrial alterations caused by defective peroxisomal biogenesis in a mouse model for Zellweger syndrome (PEX5 knockout mouse). Am J Pathol 159: 1477-1494, 2001.

16. Belousov VV, Fradkov AF, Lukyanov KA, Staroverov DB, Shakhbazov KS, Terskikh AV, and Lukyanov S. Genetically encoded fluorescent indicator for intracellular hydrogen peroxide. Nat Methods 3: 281-286, 2006.

17. Berger J, Forss-Petter S, and Eichler FS. Pathophysiology of X-linked adrenoleukodystrophy. Biochimie 98: 135-142, 2014. 
18. Berger J, Pujol A, Aubourg P, and Forss-Petter S. Current and future pharmacological treatment strategies in X-linked adrenoleukodystrophy. Brain Pathol 20: 845-856, 2010.

19. Bienert GP and Chaumont F. Aquaporin-facilitated transmembrane diffusion of hydrogen peroxide. Biochim Biophys Acta 1840: 1596-1604, 2014.

20. Bilan DS and Belousov VV. New tools for redox biology: From imaging to manipulation. Free Radic Biol Med 109: 167-188, 2017.

21. Bottelbergs A, Verheijden S, Van Veldhoven PP, Just W, Devos R, and Baes M. Peroxisome deficiency but not the defect in ether lipid synthesis causes activation of the innate immune system and axonal loss in the central nervous system. J Neuroinflammation 9: 61, 2012.

22. Boveris A, Oshino N, and Chance B. The cellular production of hydrogen peroxide. Biochem J 128: 617-663, 1972.

23. Bracalente C, Ibañez IL, Berenstein A, Notcovich C, Cerda MB, Klamt F, Chernomoretz A, and Durán H. Reprogramming human A375 amelanotic melanoma cells by catalase overexpression: Upregulation of antioxidant genes correlates with regression of melanoma malignancy and with malignant progression when downregulated. Oncotarget 7: 4115441171, 2016.

24. Brass EP. Overview of coenzyme A metabolism and its role in cellular toxicity. Chem Biol Interact 90: 203-214, 1994.

25. Bratt A, Rosenwasser S, Meyer A, and Fluhr R. Organelle redox autonomy during environmental stress. Plant Cell Environ 39: 1909-1919, 2016.

26. Brewer TF, Garcia FJ, Onak CS, Carroll KS, and Chang CJ. Chemical approaches to discovery and study of sources and targets of hydrogen peroxide redox signaling through NADPH oxidase proteins. Annu Rev Biochem 84: 765-790, 2015. 
27. Brooks RR, Weisz J, Kuemmerle NB, Salzberg AC, Berg A, Brown DG, Kubik L, Palorini R, Al-Mulla F, Al-Temaimi R, Colacci A, Mondello C, Raju J, Woodrick J, Scovassi AI, Singh N, Vaccari M, Roy R, Forte S, Memeo L, Salem HK, Amedei A, Hamid RA, Williams GP, Lowe L, Meyer J, Martin FL, Bisson WH, Chiaradonna F, and Ryan EP. Metabolic reprogramming and dysregulated metabolism: cause, consequence and/or enabler of environmental carcinogenesis? Carcinogenesis 36: S203-S231, 2015.

28. Brown MR, Miller FJ Jr, Li WG, Ellingson AN, Mozena JD, Chatterjee P, Engelhardt JF, Zwacka RM, Oberley LW, Fang X, Spector AA, and Weintraub NL. Overexpression of human catalase inhibits proliferation and promotes apoptosis in vascular smooth muscle cells. Circ Res 85: 524-533, 1999.

29. Bulina ME, Chudakov DM, Britanova OV, Yanushevich YG, Staroverov DB, Chepurnykh TV, Merzlyak EM, Shkrob MA, Lukyanov S, and Lukyanov KA. A genetically encoded photosensitizer. Nat Biotechnol 24: 95-99, 2006.

30. Cairns RA, Harris IS, and Mak TW. Regulation of cancer cell metabolism. Nat Rev Cancer 11: 85-95, 2011.

31. Carter AB, Tephly LA, Venkataraman S, Oberley LW, Zhang Y, Buettner GR, Spitz DR, and Hunninghake GW. High levels of catalase and glutathione peroxidase activity dampen $\mathrm{H}_{2} \mathrm{O}_{2}$ signaling in human alveolar macrophages. Am J Respir Cell Mol Biol 31: 43-53, 2004.

32. Carvalho AF, Pinto MP, Grou CP, Alencastre IS, Fransen M, Sá-Miranda C, and Azevedo JE. Ubiquitination of mammalian Pex5p, the peroxisomal import receptor. J Biol Chem 282: 31267-31272, 2007.

33. Chen HP, Zhao YT, and Zhao TC. Histone deacetylases and mechanisms of regulation of gene expression. Crit Rev Oncog 20: 35-47, 2015. 
34. Chen X, Liang H, Van Remmen H, Vijg J, and Richardson A. Catalase transgenic mice: characterization and sensitivity to oxidative stress. Arch Biochem Biophys 422: 197-210, 2004.

35. Childs BG, Durik M, Baker DJ, and van Deursen JM. Cellular senescence in aging and age-related disease: from mechanisms to therapy. Nat Med 21: 1424-1435, 2015.

36. Chu S, Huang Q, Alvares K, Yeldandi AV, Rao MS, and Reddy JK. Transformation of mammalian cells by overexpressing $\mathrm{H}_{2} \mathrm{O}_{2}$-generating peroxisomal fatty acyl-CoA oxidase. Proc Natl Acad Sci USA 92: 7080-7084.

37. Cipolla CM and Lodhi IJ. Peroxisomal dysfunction in age-related diseases. Trends Endocrinol Metab 28: 297-308, 2017.

38. Crane DI. Revisiting the neuropathogenesis of Zellweger syndrome. Neurochem Int 69: 1$8,2014$.

39. Cui W, Ma J, Wang X, Yang W, Zhang J, and Ji Q. Free fatty acid induces endoplasmic reticulum stress and apoptosis of $\beta$-cells by $\mathrm{Ca}^{2+} /$ calpain-2 pathways. PLoS One 8: e59921, 2013

40. De Duve C and Baudhuin P. Peroxisomes (microbodies and related particles). Physiol Rev 46: 323-357, 1966.

41. Delmaghani S, Defourny J, Aghaie A, Beurg M, Dulon D, Thelen N, Perfettini I, Zelles T, Aller M, Meyer A, Emptoz A, Giraudet F, Leibovici M, Dartevelle S, Soubigou G, Thiry M, Vizi ES, Safieddine S, Hardelin JP, Avan P, and Petit C. Hypervulnerability to sound exposure through impaired adaptive proliferation of peroxisomes. Cell 163: 894-906, 2015.

42. Delmaghani S, del Castillo FJ, Michel V, Leibovici M, Aghaie A, Ron U, Van Laer L, Ben-Tal N, Van Camp G, Weil D, Langa F, Lathrop M, Avan P, and Petit C. Mutations in 
the gene encoding pejvakin, a newly identified protein of the afferent auditory pathway, cause DFNB59 auditory neuropathy. Nat Genet 38: 770-778, 2006.

43. Dhaunsi GS and Bitar MS. Antioxidants attenuate diabetes-induced activation of peroxisomal functions in the rat kidney. J Biomed Sci 11: 566-570, 2004.

44. Diano S. Role of reactive oxygen species in hypothalamic regulation energy metabolism. Endocrinol Metab (Seoul) 28: 3-5, 2013.

45. Diano S, Liu ZW, Jeong JK, Dietrich MO, Ruan HB, Kim E, Suyama S, Kelly K, Gyengesi E, Arbiser JL, Belsham DD, Sarruf DA, Schwartz MW, Bennett AM, Shanabrough M, Mobbs CV, Yang X, Gao XB, and Horvath TL. Peroxisome proliferation-associated control of reactive oxygen species sets melanocortin tone and feeding in diet-induced obesity. Nat Med 17: 1121-1127, 2011.

46. Doherty JF, Golden MH, and Brooks SE. Peroxisomes and the fatty liver of malnutrition: an hypothesis. Am J Clin Nutr 54: 674-677, 1991.

47. Doulias PT, Tenopoulou M, Greene JL, Raju K, and Ischiropoulos H. Nitric oxide regulates mitochondrial fatty acid metabolism through reversible protein S-nitrosylation. Sci Signal 6: rs1, 2013.

48. Elsner M, Gehrmann W, and Lenzen S. Peroxisome-generated hydrogen peroxide as important mediator of lipotoxicity in insulin-producing cells. Diabetes 60: 200-208, 2011.

49. Farr RL, Lismont C, Terlecky SR, and Fransen M. Peroxisome biogenesis in mammalian cells: The impact of genes and environment. Biochim Biophys Acta 1863: 1049-1060, 2016.

50. Fechner A, Böhme C, Gromer S, Funk M, Schirmer R, and Becker K. Antioxidant status and nitric oxide in the malnutrition syndrome kwashiorkor. Pediatr Res 49: 237-243, 2001. 
51. Fourcade S, López-Erauskin J, Galino J, Duval C, Naudi A, Jove M, Kemp S, Villarroya F, Ferrer I, Pamplona R, Portero-Otin M, and Pujol A. Early oxidative damage underlying neurodegeneration in X-adrenoleukodystrophy. Hum Mol Genet 17: 1762-1773, 2008.

52. Francisco T, Rodrigues TA, Pinto MP, Carvalho AF, Azevedo JE, and Grou CP. Ubiquitin in the peroxisomal protein import pathway. Biochimie 98: 29-35, 2013.

53. Fransen M. Peroxisome dynamics: molecular players, mechanisms, and (dys)functions. ISRN Cell Biology 2012: 714192, 2012.

54. Fransen M, Nordgren M, Wang B, and Apanasets O. Role of peroxisomes in ROS/RNSmetabolism: implications for human disease. Biochim Biophys Acta 1822: 1363-1373, 2012.

55. Fransen M, Nordgren M, Wang B, Apanasets O, and Van Veldhoven PP. Aging, agerelated diseases and peroxisomes. Subcell Biochem 69: 45-65, 2013.

56. Frederiks WM, Bosch KS, Hoeben KA, van Marle J, and Langbein S. Renal cell carcinoma and oxidative stress: the lack of peroxisomes. Acta Histochem 112: 364-371, 2010.

57. Gehrmann W, Würdemann W, Plötz T, Jörns A, Lenzen S, and Elsner M. Antagonism between saturated and unsaturated fatty acids in ROS mediated lipotoxicity in rat insulinproducing cells. Cell Physiol Biochem 36: 852-865, 2015.

58. Giordano CR and Terlecky SR. Peroxisomes, cell senescence, and rates of aging. Biochim Biophys Acta 1822: 1358-1362, 2012.

59. Glorieux C, Dejeans N, Sid B, Beck R, Calderon PB, and Verrax J. Catalase overexpression in mammary cancer cells leads to a less aggressive phenotype and an altered response to chemotherapy. Biochem Pharmacol 82: 1384-1390, 2011.

60. Godo S and Shimokawa H. Divergent roles of endothelial nitric oxide synthases system in maintaining cardiovascular homeostasis. Free Radic Biol Med 109: 4-10, 2017. 
61. Góth L and Nagy T. Inherited catalase deficiency: is it benign or a factor in various age related disorders? Mutat Res 753: 147-154, 2013.

62. Gray E, Ginty M, Kemp K, Scolding N, and Wilkins A. Peroxisome proliferator-activated receptor- $\alpha$ agonists protect cortical neurons from inflammatory mediators and improve peroxisomal function. Eur J Neurosci 33: 1421-1432, 2011.

63. Gray TJ, Lake BG, Beamand JA, Foster JR, and Gangolli SD. Peroxisomal effects of phthalate esters in primary cultures of rat hepatocytes. Toxicology 28: 167-179, 1983.

64. Gutscher M, Pauleau AL, Marty L, Brach T, Wabnitz GH, Samstag Y, Meyer AJ, and Dick TP. Real-time imaging of the intracellular glutathione redox potential. Nat Methods 5: 553-539, 2008.

65. Gutscher M, Sobotta MC, Wabnitz GH, Ballikaya S, Meyer AJ, Samstag Y, and Dick TP. Proximity-based protein thiol oxidation by $\mathrm{H}_{2} \mathrm{O}_{2}$-scavenging peroxidases. $J$ Biol Chem 284: 31532-31540, 2009.

66. Hamanaka RB and Chandel NS. Mitochondrial reactive oxygen species regulate cellular signaling and dictate biological outcomes. Trends Biochem Sci 35: 505-513, 2010.

67. Hanschmann EM, Godoy JR, Berndt C, Hudemann C, and Lillig CH. Thioredoxins, glutaredoxins, and peroxiredoxins - Molecular mechanisms and health significance: from cofactors to antioxidants to redox signaling. Antioxid Redox Signal 19: 1539-1605, 2013.

68. Hanson GT, Aggeler R, Oglesbee D, Cannon M, Capaldi RA, Tsien RY, and Remington SJ. Investigating mitochondrial redox potential with redox-sensitive green fluorescent protein indicators. J Biol Chem 279: 13044-13053, 2004.

69. Hasegawa K, Wakino S, Yoshioka K, Tatematsu S, Hara Y, Minakuchi H, Sueyasu K, Washida N, Tokuyama H, Tzukerman M, Skorecki K, Hayashi K, and Itoh H. Kidneyspecific overexpression of Sirt1 protects against acute kidney injury by retaining peroxisome function. J Biol Chem 285: 13045-13056, 2010. 
70. Heit C, Marshall S, Singh S, Yu X, Charkoftaki G, Zhao H, Orlicky DJ, Fritz KS, Thompson DC, and Vasiliou V. Catalase deletion promotes prediabetic phenotype in mice. Free Radic Biol Med 103: 48-56, 2017.

71. Hellemans K, Kerckhofs K, Hannaert JC, Martens G, Van Veldhoven P, and Pipeleers D. Peroxisome proliferator-activated receptor alpha-retinoid $\mathrm{X}$ receptor agonists induce betacell protection against palmitate toxicity. FEBS J 274: 6094-6105, 2007.

72. Holmström KM and Finkel T. Cellular mechanisms and physiological consequences of redox-dependent signalling. Nat Rev Mol Cell Biol 16: 411-421, 2014.

73. Ho YS, Xiong Y, Ma W, Spector A, and Ho DS. Mice lacking catalase develop normally but show differential sensitivity to oxidant tissue injury. J Biol Chem 279: 32804-32812, 2004.

74. Hwang I, Lee J, Huh JY, Park J, Lee HB, Ho YS, and Ha H. Catalase deficiency accelerates diabetic renal injury through peroxisomal dysfunction. Diabetes 61: 728-738, 2012.

75. Ivashchenko O, Van Veldhoven PP, Brees C, Ho YS, Terlecky SR, and Fransen M. Intraperoxisomal redox balance in mammalian cells: oxidative stress and interorganellar cross-talk. Mol Biol Cell 22: 1440-1451, 2011.

76. Jo DS, Bae DJ, Park SJ, Seo HM, Kim HB, Oh JS, Chang JW, Kim SY, Shin JW, and Cho DH. Pexophagy is induced by increasing peroxisomal reactive oxygen species in 1'10phenanthroline-treated cells. Biochem Biophys Res Commun 467: 354-360, 2015.

77. Karlsson M, Kurz T, Brunk UT, Nilsson SE, and Frennesson CI. What does the commonly used DCF test for oxidative stress really show? Biochem J 428: 183-190, 2010.

78. Kasai H1, Okada Y, Nishimura S, Rao MS, and Reddy JK. Formation of 8hydroxydeoxyguanosine in liver DNA of rats following long-term exposure to a peroxsome proliferator. Cancer Res 49: 2603-2605, 1989. 
79. Kaul N and Ali S. Genes, genetics, and environment in type 2 diabetes: implication in personalized medicine. DNA Cell Biol 35: 1-12, 2016.

80. Kazmierczak M, Kazmierczak P, Peng AW, Harris SL, Shah P, Puel JL, Lenoir M, Franco SJ, and Schwander M. Pejvakin, a candidate stereociliary rootlet protein, regulates hair cell function in a cell-autonomous manner. J Neurosci 37: 3447-3464, 2017.

81. Kharroubi I, Ladrière L, Cardozo AK, Dogusan Z, Cnop M, and Eizirik DL. Free fatty acids and cytokines induce pancreatic beta-cell apoptosis by different mechanisms: role of nuclear factor-kappaB and endoplasmic reticulum stress. Endocrinology 145: 5087-5096, 2004.

82. Kemp S, Wei HM, Lu JF, Braiterman LT, McGuinness MC, Moser AB, Watkins PA, and Smith KD. Gene redundancy and pharmacological gene therapy: implications for X-linked adrenoleukodystrophy. Nat Med 4: 1261-1268, 1998.

83. Kim JH, Song J, and Park KW. The multifaceted factor peroxisome proliferator-activated receptor $\gamma(\operatorname{PPAR} \gamma)$ in metabolism, immunity, and cancer. Arch Pharm Res 38: 302-312, 2015.

84. Kirkman HN and Gaetani GF. Mammalian catalase: a venerable enzyme with new mysteries. Trends Biochem Sci 32: 44-50, 2007.

85. Kitajiri S, Sakamoto T, Belyantseva IA, Goodyear RJ, Stepanyan R, Fujiwara I, Bird JE, Riazuddin S, Riazuddin S, Ahmed ZM, Hinshaw JE, Sellers J, Bartles JR, and Hammer JA 3rd, Richardson GP, Griffith AJ, Frolenkov GI, Friedman TB. Actin-bundling protein TRIOBP forms resilient rootlets of hair cell stereocilia essential for hearing. Cell 141: 786798, 2010.

86. Knoops B, Argyropoulou V, Becker S, Ferté L, and Kuznetsova O. Multiple Roles of Peroxiredoxins in Inflammation. Mol Cells 39: 60-64, 2016. 
87. Knoops B, Goemaere J, Van der Eecken V, and Declercq JP. Peroxiredoxin 5: structure, mechanism, and function of the mammalian atypical 2-Cys peroxiredoxin. Antioxid Redox Signal 15: 817-829, 2011.

88. Koepke JI, Nakrieko KA, Wood CS, Boucher KK, Terlecky LJ, Walton PA, and Terlecky SR. Restoration of peroxisomal catalase import in a model of human cellular aging. Traffic 8: 1592-1600, 2007.

89. Koepke JI, Wood CS, Terlecky LJ, Walton PA, and Terlecky SR. Progeric effects of catalase inactivation in human cells. Toxicol Appl Pharmacol 232: 99-108, 2008.

90. Kovacs WJ, Tape KN, Shackelford JE, Wikander TM, Richards MJ, Fliesler SJ, Krisans SK, and Faust PL. Peroxisome deficiency causes a complex phenotype because of hepatic SREBP/Insig dysregulation associated with endoplasmic reticulum stress. $J$ Biol Chem 284: 7232-7245, 2009.

91. Lauer C, Volk1 A, Riedl S, Fahimi HD, and Beier K. Impairment of peroxisomal biogenesis in human colon carcinoma. Carcinogenesis 20: 985-989, 1999.

92. Laurindo FR, Fernandes DC, and Santos CX. Assessment of superoxide production and NADPH oxidase activity by HPLC analysis of dihydroethidium oxidation products. Methods Enzymol 441: 237-260, 2008.

93. Lefevre SD, van Roermund CW, Wanders RJ, Veenhuis M, and van der Klei IJ. The significance of peroxisome function in chronological aging of Saccharomyces cerevisiae. Aging Cell 12: 784-793, 2013.

94. Legakis JE, Koepke JI, Jedeszko C, Barlaskar F, Terlecky LJ, Edwards HJ, Walton PA, and Terlecky SR. Peroxisome senescence in human fibroblasts. Mol Biol Cell 13: 42434255, 2002. 
95. Lennicke C, Rahn J, Lichtenfels R, Wessjohann LA, and Seliger B. Hydrogen peroxideproduction, fate and role in redox signaling of tumor cells. Cell Commun Signal 13: 39, 2015.

96. Li X, Chen H, and Epstein PN. Metallothionein and catalase sensitize to diabetes in nonobese diabetic mice: reactive oxygen species may have a protective role in pancreatic beta-cells. Diabetes 55: 1592-1604, 2006.

97. Li Y, Tharappel JC, Cooper S, Glenn M, Glauert HP, and Spear BT. Expression of the hydrogen peroxide-generating enzyme fatty acyl CoA oxidase activates NF-kB. DNA Cell Biol 19: 113-120, 2000.

98. Lim JB, Langford TF, Huang BK, Deen WM, and Sikes HD. A reaction-diffusion model of cytosolic hydrogen peroxide. Free Radic Biol Med 90: 85-90, 2016.

99. Liepinsh E, Skapare E, Kuka J, Makrecka M, Cirule H, Vavers E, Sevostjanovs E, Grinberga S, Pugovics O, and Dambrova M. Activated peroxisomal fatty acid metabolism improves cardiac recovery in ischemia-reperfusion. Naunyn Schmiedebergs Arch Pharmacol 386: 541-550, 2013.

100.Lismont C, Nordgren M, Van Veldhoven PP, and Fransen M. Redox interplay between mitochondria and peroxisomes. Front Cell Dev Biol 3: 35, 2015.

101.Lismont C, Walton PA, and Fransen M. Quantitative monitoring of subcellular redox dynamics in living mammalian cells using RoGFP2-based probes. Methods Mol Biol 1595: $151-164,2017$.

102.Lismont C, Nordgren M, Brees C, Knoops B, Van Veldhoven PP, and Fransen M. Peroxisomes as modulators of cellular protein thiol oxidation: a new model system. Antioxid Redox Signal: in press (doi: 10.1089/ars.2017.6997).

103.Lodhi IJ and Semenkovich CF. Peroxisomes: a nexus for lipid metabolism and cellular signaling. Cell Metab 19: 380-392, 2014. 
104.López-Erauskin J, Galino J, Bianchi P, Fourcade S, Andreu AL, Ferrer I, Muñoz-Pinedo C, and Pujol A. Oxidative stress modulates mitochondrial failure and cyclophilin D function in X-linked adrenoleukodystrophy. Brain 135: 3584-3598, 2012.

105.López-Erauskin J, Galino J, Ruiz M, Cuezva JM, Fabregat I, Cacabelos D, Boada J, Martínez J, Ferrer I, Pamplona R, Villarroya F, Portero-Otín M, Fourcade S, and Pujol A. Impaired mitochondrial oxidative phosphorylation in the peroxisomal disease $\mathrm{X}$ linkedadrenoleukodystrophy. Hum Mol Genet 2013: 3296-3305, 2013.

106.Manary MJ, Leeuwenburgh C, and Heinecke JW. Increased oxidative stress in kwashiorkor. J Pediatr 137: 421-424, 2000.

107.Mardones $\mathrm{P}$ and Hetz C. Peroxisomes get loud: a redox antidote to hearing loss. Cell 163: 790-791, 2015.

108. Marengo B, Nitti M, Furfaro AL, Colla R, Ciucis CD, Marinari UM, Pronzato MA, Traverso N, and Domenicotti C. Redox homeostasis and cellular antioxidant systems: crucial players in cancer growth and therapy. Oxid Med Cell Longev 2016: 6235641, 2016.

109.Margoliash E, Novogrodsky A, and Schejter A. Irreversible reaction of 3-amino-1,2,4triazole and related inhibitors with the protein of catalase. Biochem $J$ 74: 339-348, 1960.

110.McClelland GB, Khanna S, González GF, Butz CE, and Brooks GA. Peroxisomal membrane monocarboxylate transporters: evidence for a redox shuttle system. Biochem Biophys Res Commun 304: 130-135, 2003.

111.Min XL, Wang TY, Cao Y, Liu J, Li JT, and Wang TH. MicroRNAs: a novel promising therapeutic target for cerebral ischemia/reperfusion injury? Neural Regen Res 10: 1799$1808,2015$.

112.Misra P, Viswakarma N, and Reddy JK. Peroxisome proliferator-activated receptor- $\alpha$ signaling in hepatocarcinogenesis. Subcell Biochem 69: 77-99, 2013. 
113. Mitchell AM, Bridges JW, and Elcombe CR. Factors influencing peroxisome proliferation in cultured rat hepatocytes. Arch Toxicol 55: 239-246, 1984.

114.Morita A and Tanimoto K, Murakami T, Morinaga T, Hosoi Y. Mitochondria are required for ATM activation by extranuclear oxidative stress in cultured human hepatoblastoma cell line Hep G2 cells. Biochem Biophys Res Commun 443: 1286-1290, 2014.

115.Muller M. Cellular senescence: molecular mechanisms, in vivo significance, and redox considerations. Antioxid Redox Signal 11: 59-98, 2009.

116.Müller CC, Nguyen TH, Ahlemeyer B, Meshram M, Santrampurwala N, Cao S, Sharp P, Fietz PB, Baumgart-Vogt E, and Crane DI. PEX13 deficiency in mouse brain as a model of Zellweger syndrome: abnormal cerebellum formation, reactive gliosis and oxidative stress. Dis Model Mech 4: 104-119, 2011.

117.Nauseef WM. Detection of superoxide anion and hydrogen peroxide production by cellular NADPH oxidases. Biochim Biophys Acta 1840: 757-767, 2014.

118. Netto LE and Antunes F. The roles of peroxiredoxin and thioredoxin in hydrogen peroxide sensing and in signal transduction. Mol Cells 39: 65-71, 2016.

119.Neuberger G, Maurer-Stroh S, Eisenhaber B, Hartig A, and Eisenhaber F. Motif refinement of the peroxisomal targeting signal 1 and evaluation of taxon-specific differences. J Mol Biol 328: 567-579, 2003.

120.Nordgren M and Fransen M. Peroxisomal metabolism and oxidative stress. Biochimie 98 : $56-62,2014$.

121.Nordgren M, Francisco T, Lismont C, Hennebel L, Brees C, Wang B, Van Veldhoven PP, Azevedo JE, and Fransen M. Export-deficient monoubiquitinated PEX5 triggers peroxisome removal in SV40 large T antigen-transformed mouse embryonic fibroblasts. Autophagy 11: 1326-1340, 2015. 
122.Nordgren M, Wang B, Apanasets O, and Fransen M. Peroxisome degradation in mammals: mechanisms of action, recent advances, and perspectives. Front Physiol 4: 145, 2013.

123. Okamoto M, Reddy JK, and Oyasu R. Tumorigenic conversion of a non-tumorigenic rat urothelial cell line by overexpression of $\mathrm{H}_{2} \mathrm{O}_{2}$-generating peroxisomal fatty acyl-CoA oxidase. Int J Cancer 70: 716-721, 1997.

124.Oku M and Sakai Y. Assessment of physiological redox state with novel FRET protein probes. Antioxid Redox Signal 16: 698-704, 2012.

125. Okumoto K, Noda H, and Fujiki Y. Distinct modes of ubiquitination of peroxisometargeting signal type 1 (PTS1) receptor Pex5p regulate PTS1 protein import. J Biol Chem 289: 14089-14108, 2014.

126. Olowookere JO, Olorunsogo OO, and Malomo SO. Effects of defective in vivo synthesis of mitochondrial proteins on cellular biochemistry and physiology of malnourished rats. Ann Nutr Metab 34: 147-154, 1990.

127. Onumah OE, Jules GE, Zhao Y, Zhou L, Yang H, and Guo Z. Overexpression of catalase delays G0/G1- to S-phase transition during cell cycle progression in mouse aortic endothelial cells. Free Radic Biol Med 46: 1658-1667, 2009.

128. Oruqaj G, Karnati S, Vijayan V, Kotarkonda LK, Boateng E, Zhang W, Ruppert C, Günther A, Shi W, and Baumgart-Vogt E. Compromised peroxisomes in idiopathic pulmonary fibrosis, a vicious cycle inducing a higher fibrotic response via TGF- $\beta$ signaling. Proc Natl Acad Sci USA 112: E2048-E2057, 2015.

129.Pace NJ and Weerapana E. Diverse functional roles of reactive cysteines. ACS Chem Biol 8: 283-296, 2013.

130.Pacher P, Beckman JS, and Liaudet L. Nitric oxide and peroxynitrite in health and disease. Physiol Rev 87: 315-424, 2007. 
131.Packer L, Witt EH, and Tritschler HJ. Alpha-lipoic acid as a biological antioxidant. Free Radic Biol Med 19: 227-250, 1995.

132.Paulsen CE and Carroll KS. Cysteine-mediated redox signaling: chemistry, biology, and tools for discovery. Chem Rev 113: 4633-4679, 2013.

133.Pawlak M, Lefebvre P, and Staels B. Molecular mechanism of PPAR $\alpha$ action and its impact on lipid metabolism, inflammation and fibrosis in non-alcoholic fatty liver disease. J Hepatol 62: 720-733, 2015.

134.Peeters A, Shinde AB, Dirkx R, Smet J, De Bock K, Espeel M, Vanhorebeek I, Vanlander A, Van Coster R, Carmeliet P, Fransen M, Van Veldhoven PP, and Baes M. Mitochondria in peroxisome-deficient hepatocytes exhibit impaired respiration, depleted DNA, and PGC-1 $\alpha$ independent proliferation. Biochim Biophys Acta 1853: 285-298, 2015.

135.Petriv OI and Rachubinski RA. Lack of peroxisomal catalase causes a progeric phenotype in Caenorhabditis elegans. J Biol Chem 279: 19996-20001, 2004.

136.Prinzen FW, Van der Vusse GJ, Arts T, Roemen TH, Coumans WA, and Reneman RS. Accumulation of nonesterified fatty acids in ischemic canine myocardium. Am J Physiol 247: H264-H272, 1984.

137.Purdue PE and Lazarow PB. Targeting of human catalase to peroxisomes is dependent upon a novel COOH-terminal peroxisomal targeting sequence. J Cell Biol 134: 849-862, 1996.

138.Rakhshandehroo M, Knoch B, Müller M, and Kersten S. Peroxisome proliferator-activated receptor alpha target genes. PPAR Res 2010: pii 612089, 2010.

139.Reddy JK, Azarnoff DL, and Hignite CE. Hypolipidaemic hepatic peroxisome proliferators form a novel class of chemical carcinogens. Nature 283: 397-398, 1980. 
140.Rokka A, Antonenkov VD, Soininen R, Immonen HL, Pirilä PL, Bergmann U, Sormunen RT, Weckström M, Benz R, and Hiltunen JK. Pxmp2 is a channel-forming protein in mammalian peroxisomal membrane. PLoS One 4: e5090, 2009.

141.Roma LP, Duprez J, Takahashi HK, Gilon P, Wiederkehr A, and Jonas JC. Dynamic measurements of mitochondrial hydrogen peroxide concentration and glutathione redox state in rat pancreatic $\beta$-cells using ratiometric fluorescent proteins: confounding effects of pH with HyPer but not roGFP1. Biochem J 441: 971-978, 2012.

142.Rudyk $\mathrm{O}$ and Eaton P. Biochemical methods for monitoring protein thiol redox in biological systems. Redox Biol 2: 803-813, 2014.

143.Ruiz-Ojeda FJ, Gomez-Llorente C, Aguilera CM, Gil A, and Rupérez AI. Impact of 3amino-1,2,4-triazole (3-AT)-derived increase in hydrogen peroxide levels on inflammation and metabolism in human differentiated adipocytes. PLoS One 11: e0152550, 2016.

144.Rusnak F and Reiter T. Sensing electrons: protein phosphatase redox regulation. Trends Biochem Sci 25: 527-529, 2000.

145.Santanam N, Aug N, Zhou M, Keshava C, and Parthasarathy S. Overexpression of human catalase gene decreases oxidized lipid-induced cytotoxicity in vascular smooth muscle cells. Arterioscler Thromb Vasc Biol 19: 1912-1917, 1999.

146.Santos MJ, Quintanilla RA, Toro A, Grandy R, Dinamarca MC, Godoy JA, and Inestrosa NC. Peroxisomal proliferation protects from beta-amyloid neurodegeneration. $J$ Biol Chem 280: 41057-41068, 2005.

147.Scherz-Shouval R, Shvets E, Fass E, Shorer H, Gil L, and Elazar Z. Reactive oxygen species are essential for autophagy and specifically regulate the activity of Atg4. EMBOJ 26: 1749-1760, 2007. 
148. Schieber M and Chandel NS. ROS function in redox signaling and oxidative stress. Curr Biol 24: R453-R462, 2014.

149.Schrader M, Costello JL, Godinho LF, Azadi AS, and Islinger M. Proliferation and fission of peroxisomes - an update. Biochim Biophys Acta 1863: 971-983, 2016.

150.Schriner SE, Smith AC, Dang NH, Fukuchi K, and Martin GM. Overexpression of wildtype and nuclear-targeted catalase modulates resistance to oxidative stress but does not alter spontaneous mutant frequencies at APRT. Mutat Res 449: 21-31, 2000.

151.Schwarzländer M, Dick TP, Meyer AJ, and Morgan B. Dissecting Redox Biology Using Fluorescent Protein Sensors. Antioxid Redox Signal 24: 680-712, 2016.

152. Sena LA and Chandel NS. Physiological roles of mitochondrial reactive oxygen species. Mol Cell 48: 158-167, 2012.

153.Soh S, Byrska M, Kandere-Grzybowska K, and Grzybowski BA. Reaction-diffusion systems in intracellular molecular transport and control. Angew Chem Int Ed Engl 49: 4170-4198, 2010.

154.Syed DN and Mukhtar H. Gender bias in skin cancer: role of catalase revealed. J Invest Dermatol 132: 512-514.

155.Shai N, Schuldiner M, and Zalckvar E. No peroxisome is an island - Peroxisome contact sites. Biochim Biophys Acta 1863: 1061-1069, 2016.

156.Sies H. Hydrogen peroxide as a central redox signaling molecule in physiological oxidative stress: Oxidative eustress. Redox Biol 11: 613-619, 2017.

157. Singh I, Singh AK, and Contreras MA. Peroxisomal dysfunction in inflammatory childhood white matter disorders: an unexpected contributor to neuropathology. $J$ Child Neurol 24: 1147-1157, 2009. 
158. Singh AK, Dhaunsi GS, Gupta MP, Orak JK, Asayama K, and Singh I. Demonstration of glutathione peroxidase in rat liver peroxisomes and its intraorganellar distribution. Arch Biochem Biophys 315: 331-338, 1994.

159. Terlecky SR, Koepke JI, and Walton PA. Peroxisomes and aging. Biochim Biophys Acta 1763: 1749-1754, 2006.

160.Trompier D, Vejux A, Zarrouk A, Gondcaille C, Geillon F, Nury T, Savary S, and Lizard G. Brain peroxisomes. Biochimie 98: 102-110, 2014.

161.Turecký L, Kupčová V, Uhlíková E, and Mojto V. Peroxisomal enzymes in the liver of rats with experimental diabetes mellitus type 2. Physiol Res 63: S585-S591, 2014.

162.Valença I, Pértega-Gomes N, Vizcaino JR, Henrique RM, Lopes C, Baltazar F, and Ribeiro D. Localization of MCT2 at peroxisomes is associated with malignant transformation in prostate cancer. J Cell Mol Med 19: 723-733, 2015.

163.van der Vliet A and Janssen-Heininger YM. Hydrogen peroxide as a damage signal in tissue injury and inflammation: murderer, mediator, or messenger? J Cell Biochem 115: 427-435, 2014

164. Van Veldhoven PP. Biochemistry and genetics of inherited disorders of peroxisomal fatty acid metabolism. J Lipid Res 51: 2863-2895, 2010.

165.van Zutphen T, Ciapaite J, Bloks VW, Ackereley C, Gerding A, Jurdzinski A, de Moraes RA, Zhang L, Wolters JC, Bischoff R, Wanders RJ, Houten SM, Bronte-Tinkew D, Shatseva T, Lewis GF, Groen AK, Reijngoud DJ, Bakker BM, Jonker JW, Kim PK, and Bandsma RH. Malnutrition-associated liver steatosis and ATP depletion is caused by peroxisomal and mitochondrial dysfunction. J Hepatol 65: 1198-1208, 2016.

166.Vasko R. Peroxisomes and kidney injury. Antioxid Redox Signal 25: 217-231, 2016.

167.Wadley AJ, Aldred S, and Coles SJ. An unexplored role for peroxiredoxin in exerciseinduced redox signalling? Redox Biol 8: 51-58, 2016. 
168. Walbrecq G, Wang B, Becker S, Hannotiau A, Fransen M, and Knoops B. Antioxidant cytoprotection by peroxisomal peroxiredoxin-5. Free Radic Biol Med 84: 215-226, 2015.

169.Wali G, Sutharsan R, Fan Y, Stewart R, Tello Velasquez J, Sue CM, Crane DI, and Mackay-Sim A. Mechanism of impaired microtubule-dependent peroxisome trafficking and oxidative stress in SPAST-mutated cells from patients with Hereditary Spastic Paraplegia. Sci Rep 6: 27004, 2016.

170.Walter KM, Schönenberger MJ, Trötzmüller M, Horn M, Elsässer HP, Moser AB, Lucas MS, Schwarz T, Gerber PA, Faust PL, Moch H, Köfeler HC, Krek W, and Kovacs WJ. Hif- $2 \alpha$ promotes degradation of mammalian peroxisomes by selective autophagy. Cell Metab 20: 882-897, 2014.

171.Walton PA and Pizzitelli M. Effects of peroxisomal catalase inhibition on mitochondrial function. Front Physiol 3: 108, 2012.

172.Wanders RJ and Waterham HR. Biochemistry of mammalian peroxisomes revisited. Annu Rev Biochem 75: 295-332, 2006.

173.Wang B, Apanasets O, Nordgren M, and Fransen M. Dissecting peroxisome-mediated signaling pathways: a new and exciting research field. In 'Molecular machines involved in peroxisome biogenesis and maintenance, Chapter 11, 255-273, 2014' (Springer), Editors: Brocard C and Hartig A.

174.Wang B, Van Veldhoven PP, Brees C, Rubio N, Nordgren M, Apanasets O, Kunze M, Baes M, Agostinis P, and Fransen M. Mitochondria are targets for peroxisome-derived oxidative stress in cultured mammalian cells. Free Radic Biol Med 65: 882-894, 2013.

175.Waterham HR, Ferdinandusse S, and Wanders RJ. Human disorders of peroxisome metabolism and biogenesis. Biochim Biophys Acta 1863: 922-933, 2016. 
176.Weng H, Ji X, Endo K, and Iwai N. Pex11 $\alpha$ deficiency is associated with a reduced abundance of functional peroxisomes and aggravated renal interstitial lesions. Hypertension 64: 1054-1060, 2014.

177.Winterbourn CC. The challenges of using fluorescent probes to detect and quantify specific reactive oxygen species in living cells. Biochim Biophys Acta 1840: 730-738, 2014.

178. Wood CS, Koepke JI, Teng H, Boucher KK, Katz S, Chang P, Terlecky LJ, Papanayotou I, Walton PA, and Terlecky SR. Hypocatalasemic fibroblasts accumulate hydrogen peroxide and display age-associated pathologies. Traffic 7: 97-107, 2006.

179.Yang Y, Song Y, and Loscalzo J. Regulation of the protein disulfide proteome by mitochondria in mammalian cells. Proc Natl Acad Sci USA 104: 10813-10817, 2007.

180. Yano T, Oku M, Akeyama N, Itoyama A, Yurimoto H, Kuge S, Fujiki Y, and Sakai Y. A novel fluorescent sensor protein for visualization of redox states in the cytoplasm and in peroxisomes. Mol Cell Biol 30: 3758-3766, 2010.

181. Yao C, Behring JB, Shao D, Sverdlov AL, Whelan SA, Elezaby A, Yin X, Siwik DA, Seta F, Costello CE, Cohen RA, Matsui R, Colucci WS, McComb ME, and Bachschmid MM. Overexpression of catalase diminishes oxidative cysteine modifications of cardiac proteins. PLoS One 10: e0144025, 2015.

182. Yeldandi AV, Rao MS, and Reddy JK. Hydrogen peroxide generation in peroxisome proliferator-induced oncogenesis. Mutat Res 448: 159-177, 2000.

183.Young CN, Koepke JI, Terlecky LJ, Borkin MS, Boyd Savoy L, and Terlecky SR. Reactive oxygen species in tumor necrosis factor-alpha-activated primary human keratinocytes: implications for psoriasis and inflammatory skin disease. $J$ Invest Dermatol 128: 2606-2614, 2008. 
184.Zha S, Ferdinandusse S, Hicks JL, Denis S, Dunn TA, Wanders RJ, Luo J, De Marzo AM, and Isaacs WB. Peroxisomal branched chain fatty acid beta-oxidation pathway is upregulated in prostate cancer. Prostate 63: 316-323, 2005.

185.Zhang J, Kim J, Alexander A, Cai S, Tripathi DN, Dere R, Tee AR, Tait-Mulder J, Di Nardo A, Han JM, Kwiatkowski E, Dunlop EA, Dodd KM, Folkerth RD, Faust PL, Kastan MB, Sahin M, and Walker CL. A tuberous sclerosis complex signaling node at the peroxisome regulates mTORC1 and autophagy in response to ROS. Nat Cell Biol 15: 1186-1196, 2013.

186.Zhang J, Tripathi DN, Jing J, Alexander A, Kim J, Powell RT, Dere R, Tait-Mulder J, Lee JH, Paull TT, Pandita RK, Charaka VK, Pandita TK, Kastan MB, and Walker CL. ATM functions at the peroxisome to induce pexophagy in response to ROS. Nat Cell Biol 17: 1259-1269, 2015.

187.Zito E. ERO1: A protein disulfide oxidase and $\mathrm{H}_{2} \mathrm{O}_{2}$ producer. Free Radic Biol Med 83: 299-304, 2015. 


\section{Legends to Figures}

FIG. 1. Protein thiol redox transitions in cell signaling. Depending on their local environment, protein cysteine thiols can exist in either a protonated or deprotonated form. The deprotonated thiolate form can easily react with $\mathrm{H}_{2} \mathrm{O}_{2}$ (corresponding gradient indicated in pink) and ${ }^{\circ O}$ (corresponding gradient indicated in blue) to form sulfenic acids and Snitrosothiols, respectively. The unstable sulfenic acid intermediates can be further oxidized by $\mathrm{H}_{2} \mathrm{O}_{2}$ to form sulfinic acids or reduced to a disulfide bond by reaction with glutathione or interor intramolecular protein thiols (72). Prolonged exposure to $\mathrm{H}_{2} \mathrm{O}_{2}$ may hyperoxidize sulfinic acids to sulfonic acids. Thiolate anions may be oxidized by $\mathrm{H}_{2} \mathrm{O}_{2}$ either directly or indirectly through a redox relay system (see lower inset). Most thiol modifications are reversible, and the reduction steps are mainly catalyzed by glutaredoxins, thioredoxins, and peroxiredoxins. Given that redox-sensitive cysteines may serve as active sites for metal-binding ligands, nucleophilic catalysis, and sites of allosteric regulation on proteins from diverse classes (see upper inset), these modifications have the ability to elicit different biological responses (129).

FIG. 2. Beneficial and detrimental effects of $\mathrm{H}_{2} \mathrm{O}_{2}$ on cell fate and disease development. Schematic overview depicting the key role of $\mathrm{H}_{2} \mathrm{O}_{2}$ (corresponding gradient indicated in red) in cell fate regulation and disease development. Note that the biological toxicity of $\mathrm{H}_{2} \mathrm{O}_{2}$ is most likely caused by its transition metal-catalyzed conversion into hydroxyl radicals.

FIG. 3. Schematic overview of peroxisomal enzymes that produce or degrade ROS/RNS. Peroxisomes contain multiple flavin-dependent oxidoreductases (oxidases) that produce hydrogen peroxide $\left(\mathrm{H}_{2} \mathrm{O}_{2}\right)$ or superoxide $\left(\mathrm{O}_{2}{ }^{\bullet-}\right)$ as part of their normal catalytic cycle. In addition, the organelles contain inducible nitric oxide synthase (NOS2), a nitric oxide $\left({ }^{\circ} \mathrm{NO}\right)$ producing enzyme. $\mathrm{H}_{2} \mathrm{O}_{2}, \mathrm{O}_{2}{ }^{\bullet-}$, and ${ }^{\bullet} \mathrm{NO}$ can readily react with each other or with other 
biomolecules to form peroxynitrite $\left(\mathrm{ONOO}^{-}\right)$, hydroxyl radical $\left({ }^{\circ} \mathrm{OH}\right)$, and alkyl peroxides $(\mathrm{LOOH})$. Peroxisomes are also equipped with a panel of antioxidant enzymes, including catalase (CAT), superoxide dismutase 1 (SOD1), peroxiredoxin 5 (PRDX5), glutathione Stransferase kappa 1 (GSTK1), and glutathione peroxidase (GPX). Depending on the organism, cell type, physiological state, and microenvironment, the organelles may function as a source or sink of $\mathrm{H}_{2} \mathrm{O}_{2}$. How this molecule as well as many other metabolites diffuse across the peroxisomal membrane, remains to be investigated. Pro- and antioxidant factors are indicated in red and green, respectively.

FIG. 4. Strategies to manipulate and detect peroxisomal ROS production. Schematic overview depicting the methods and tools that have already been successfully used to modulate (left panel) and detect (right panel) peroxisomal ROS fluxes at the cellular level (see text for more details). The green arrows and red T-bar arrows represent stimulating and inhibiting factors, respectively. Pro- and antioxidant enzymes are indicated in pink (or red) and green, respectively. 3-AT, 3-amino-1,2,4-triazole; ACOX1, acyl-CoA oxidase 1; CAT, catalase; DAO, D-amino acid oxidase; GSH, reduced glutathione; GSSG, oxidized glutathione; GSTK1, glutathione S-transferase kappa 1; $\mathrm{H}_{2} \mathrm{DCFDA}$, dichlorodihydrofluorescein diacetate; HDAC, histone deacetylase; ORP1, oxidant receptor peroxidase 1; PPAR, peroxisome proliferatoractivated receptor; roGFP2, redox-sensitive variant of the enhanced green fluorescent protein; -SKL, prototypic peroxisomal targeting signal; SOD1, superoxide dismutase 1.

FIG. 5. Proteins and cellular processes targeted by peroxisomal ROS/RNS. Schematic overview of the currently identified proteins and processes that can be directly related to peroxisomal redox metabolism (see text for more details). Protein targets for $\mathrm{H}_{2} \mathrm{O}_{2}$ and ${ }^{\bullet} \mathrm{NO}$ are indicated in pink and purple, respectively. ACAA1, peroxisomal 3-oxoacyl-coenzyme A thiolase; ACOX1, acyl-CoA oxidase 1; ATM, ataxia telangiectasia mutated; CAT, catalase; FOXO, forkhead box O; NFKB1, nuclear factor kappa B subunit 1; PEX, peroxin; RELA, 
nuclear factor kappa B subunit RELA proto-oncogene; PTEN, phosphatase and tensin homolog.

FIG. 6. Model depicting the role of peroxisomal redox state in health and disease. Peroxisomes have the intrinsic ability to mediate and modulate redox-driven signaling events, and imbalances in peroxisomal redox metabolism have been associated with multiple disease states. Conditions leading to the production of excessive amounts of $\mathrm{H}_{2} \mathrm{O}_{2}$ (e.g., selective upregulation of peroxisomal $\beta$-oxidation) have been linked to DNA damage, malignant transformation, and tumor development; low CAT activity increases the risk for cancer and diabetes; and high CAT levels may inhibit cell proliferation and increase apoptosis. On the other hand, an increase in the number of peroxisomes without redox abnormalities was found to protect cells, tissues, and animals against oxidative insults associated with aging and agerelated disease. 
Figure 1

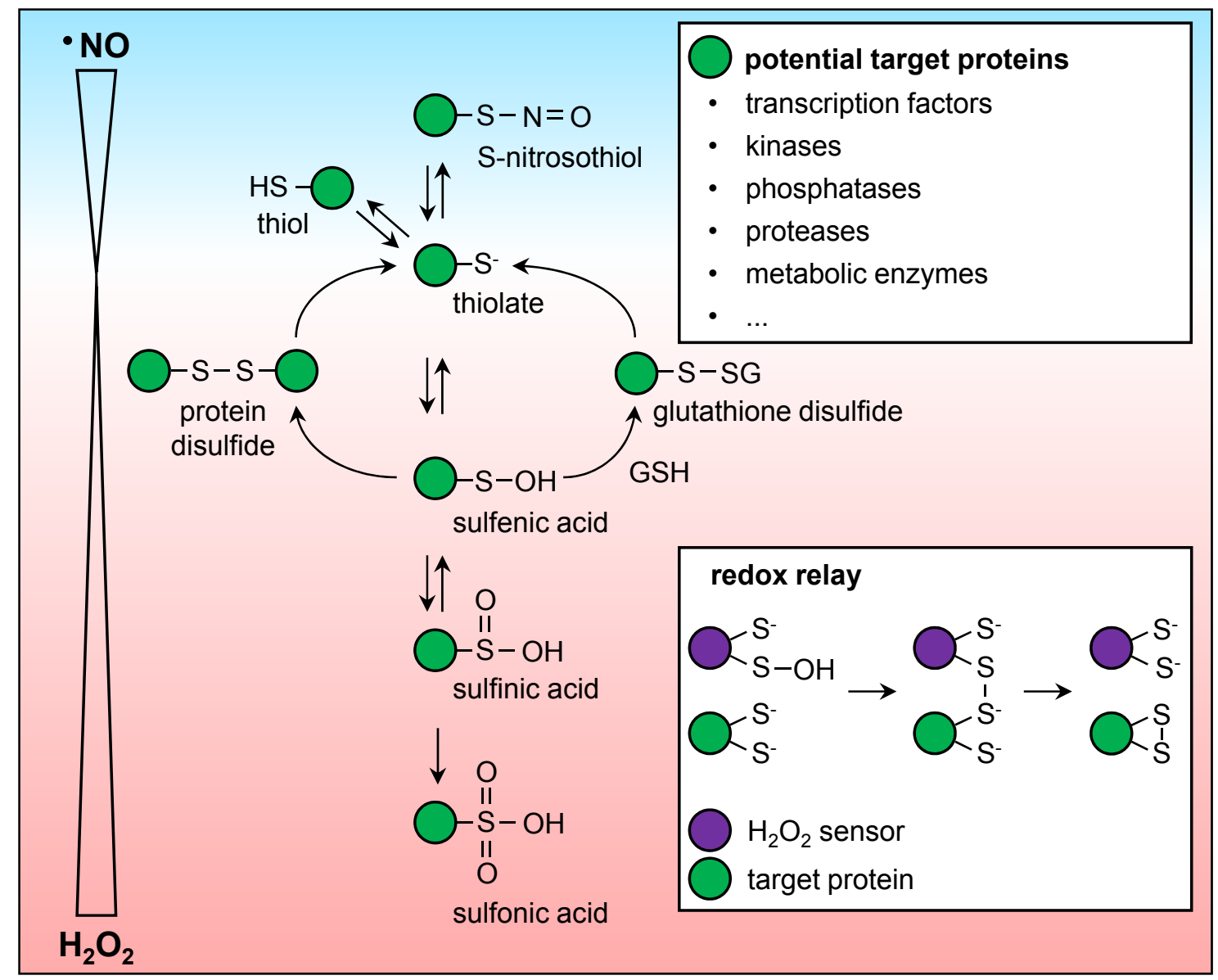




\section{$\mathrm{H}_{2} \mathrm{O}_{2} \stackrel{\text { metal }}{\longrightarrow} \cdot \mathrm{OH}$}

REDUCTIVE

STRESS

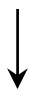

cell death

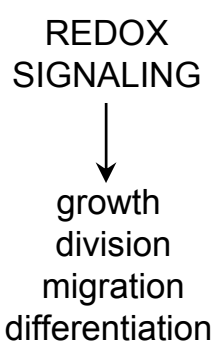

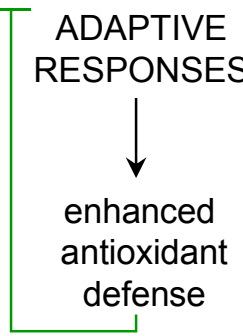

OXIDATIVE

DAMAGE

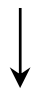

senescence

inflammation cell death
- metabolic syndrome

- obesity

- diabetes

- autoimmune disease

- cardiovascular disease

- neurological disorders

- cancer

- ... 


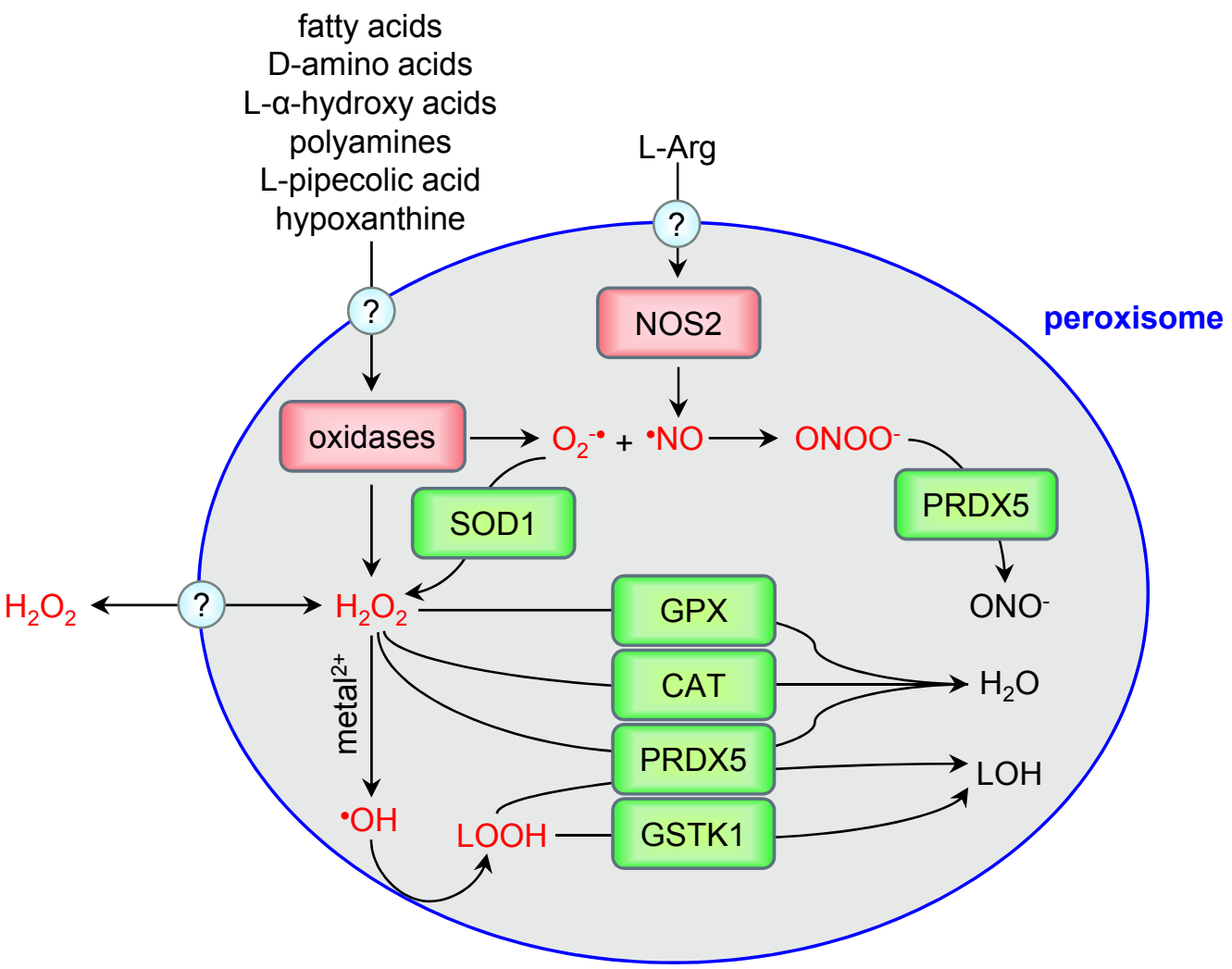




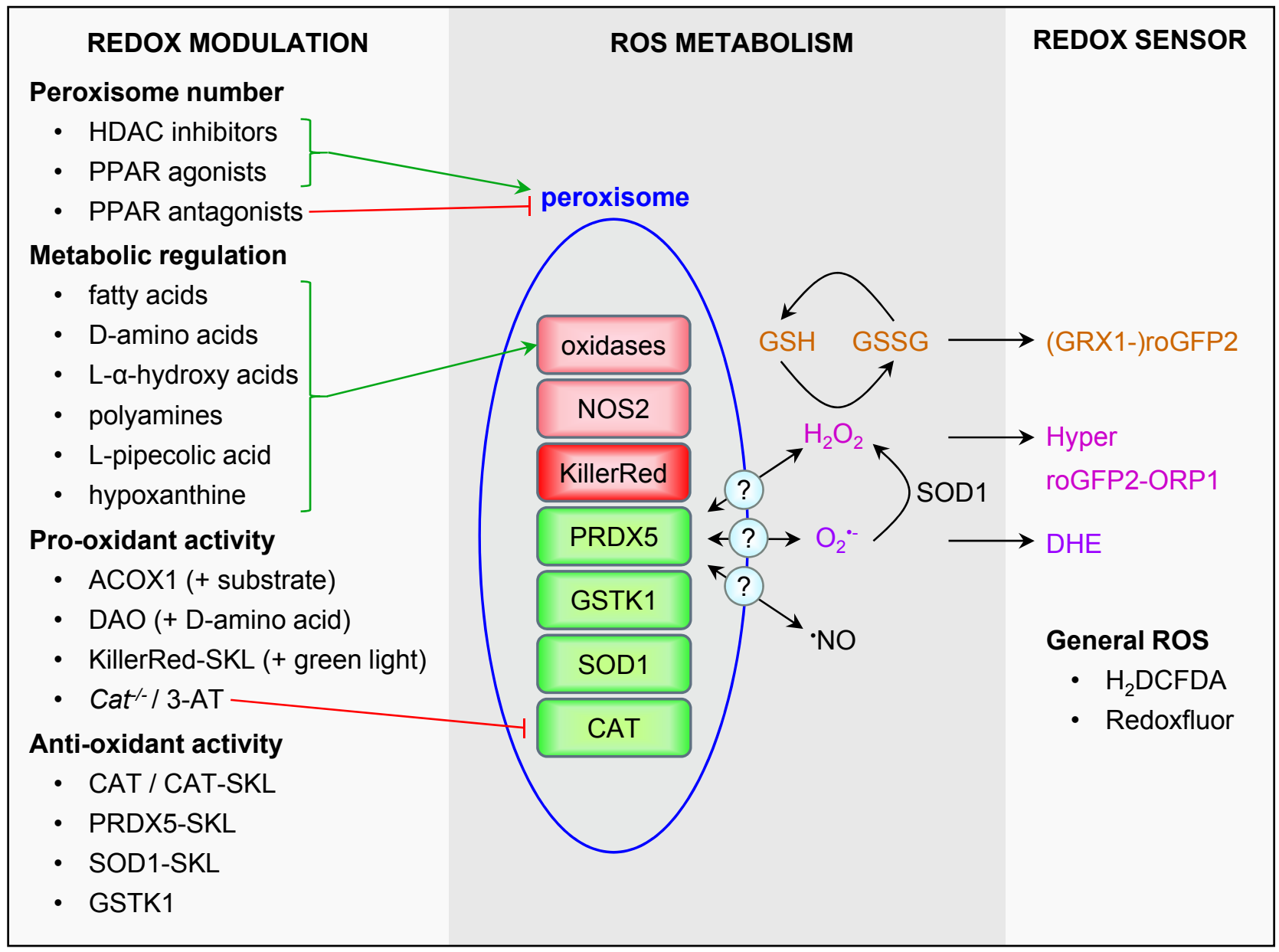




\section{Protein targets}

- NFKB1

- RELA

- PTEN

oxidases

$\leftarrow$ ? $\rightarrow \mathrm{H}_{2} \mathrm{O}_{2} \longrightarrow$

CAT

NOS2
- FOXO3

- ATM

- PEX5

- ACOX1

- CAT

- PEX11a

- ACAA1
Redox-regulated processes

- gene expression

- cell proliferation

- cell differentiation

- autophagy

- inflammation

- senescence

- cell death

- peroxisome biogenesis

- peroxisomal $\beta$-oxidation

- mitochondrial function 
Increased risk for cancer and diabetes

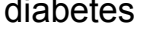

Healthy aging

peroxisome
DNA damage

Malignant transformation Tumor development

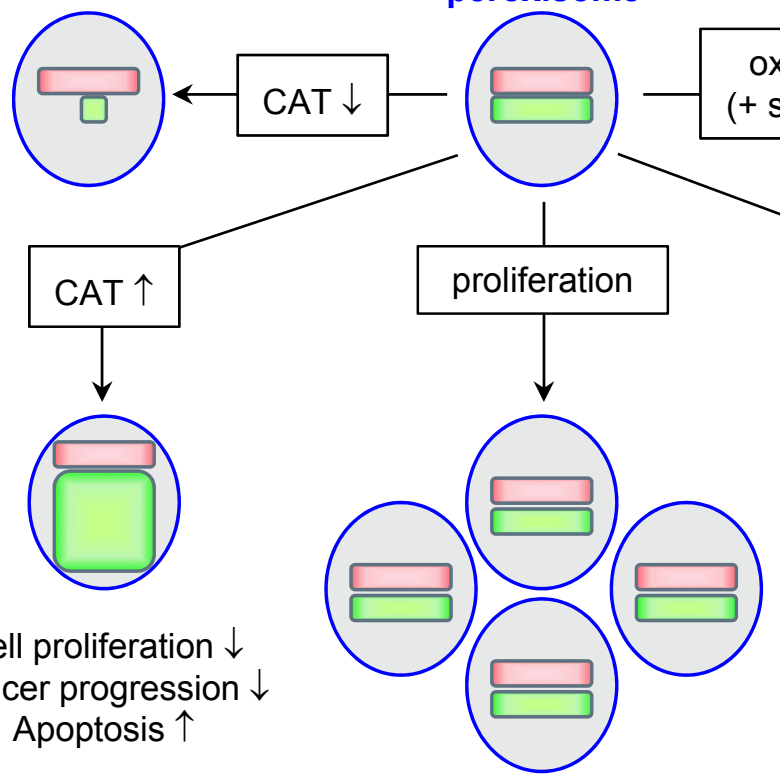

Protective against:

- diabetes

- neurodegeneration

- ischemia-reperfusion

- kwashiorkor

- noise-induced hearing loss

\section{CAT}

PPAR agonist-induced proliferation (rodents)

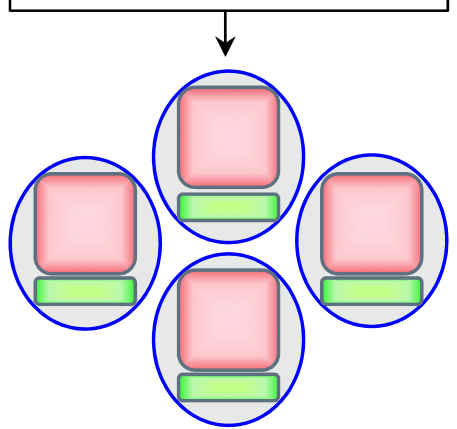

DNA damage Malignant transformation Tumor development 